\begin{tabular}{|c|c|c|c|}
\hline & \multicolumn{2}{|c|}{ R\&S - RESEARCH STUDIES ANATOLIA JOURNAL } & $=$ \\
\hline Anatolia Journal & www.dergipark.gov.tr/rs & Vol: 2, Issue: 4 pp: 1-.20 & \\
\hline
\end{tabular}

Uluyol 0, (2019). "Akademisyenlerin Yatırım Araçlarını Tanıma ve Bu Araçlara Yatırım Yapma Durumlarının İncelenmesi: Türkiye Uygulaması", Vol: 2 Issue: 4 pp: 1-20

Anahtar Kelimeler: Yatırım Araçları, Yatırım

Araçlarını Tanıma, Bu araçlara Yatırım

Keywords: Investment instruments, Recognition of investment instruments, Investment in these instruments

Makale Türü Araştırma Makalesi

\title{
AKADEMİSYENLERIN YATIRIM ARAÇLARINI TANIMA VE BU ARAÇLARA YATIRIM YAPMA DURUMLARININ İNCELENMESİ: TÜRKIYE UYGULAMASI
}

\author{
Investigating to which Extend the Academics Know the Investment Instruments and \\ Their Investments in These Instruments: Turkey Application
}

Osman ULUYOL*
Geliş Tarihi / Arrived Date
19.10.2018
Kabul Tarihi / Accepted Date
Yayınlanma Tarihi / Published Date
01.01.2019
31.01.2019

\begin{abstract}
ÖZ
$\mathrm{Bu}$ araştırmanın amacı, akademisyenlerin yatırım araçları hakkındaki bilgi düzeyini ve çeşitli yatırım araçlarına yatırım yapma durumlarını araştırmaktır. Araștırmaya konu olan veriler 30 farklı devlet üniversitesinde görev yapan 653 akademisyenden bu makalenin yazarı tarafindan hazırlanan ve \% 91,3 oranında yüksek düzeyde güvenilirliğe sahip anket formunun internet üzerinden gönderilmesi ile elde edilmiştir. Elde edilen veriler frekans analizi ve parametrik olmayan istatistiksel analiz tekniklerinden Mann Whitney U Testi ve Kruskal Wallis Testi ile değerlendirilmiştir. Araştırmadan frekans dağılımı ile elde edilen sonuçlar şu şekildedir: Akademisyenlerin en çok tanıdığı bireysel yatırım araçları sırayla "altın", "döviz", "gayrimenkul", "otomobil" ve "bireysel emeklilik" sistemidir. En çok yatırım yapılan bireysel yatırım araçları ise "bireysel emeklilik sistemi", "gayrimenkul", "altın”, “otomobil” ve "döviz" olarak bulunmuştur. Mann Whitney U ve Kruskal Wallis Testi sonuçlarına göre "cinsiyet", "çalışma alanı", "gelir düzeyi" ve "tasarruf" değișkenleriyle yatırım araçlarını tanıma ve bu yatırım araçlarına yatırım yapma konusunda istatistiksel açıdan anlamlı farklılık gözlemlenmiştir.
\end{abstract}

ABSTRACT

The aim of this research is to investigate the knowledge level of academicians about investment instruments and to invest in various investment tools. The data subject to the study were obtained from 653 academicians who work in 30 different state universities by sending the questionnaire form which is prepared by the author of this article with high reliability level of $91.3 \%$. The data obtained were evaluated by frequency analysis and nonparametric statistical analysis techniques (Mann Whitney $U$ and Kruskal Wallis Test). The frequency distribution results obtained from the research are as follows: The most well-known individual investment instruments are "gold", "foreign exchange", "real estate", "automobile" and "individual pension system". The individual investment vehicles the most invested in are the "private pension system", "real estate", "gold", "automobile" and "foreign currency". According to the results of Mann Whitney $U$ and Kruskal Wallis Tests, a statistically significant difference was observed on recognizing the investment tools and investing in them in terms of "gender", "field of study", "level of income" and "level of savings" variables.

\section{GíRiş}

Yatırım, bakış açısına göre farklı anlamları olan bir kavramdır. Örneğin; birey açısından yatırım, bir işletme için yatırım ve ekonomik anlamda yatırım birbirinden farklıdır. Halk arasında yatırım, sermayenin herhangi bir iş alanında kullanılmasını ifade etmekteyken, finansal anlamda ise hisse senedi, tahvil, bono veya gayrimenkul gibi varlıkların satın alınmasını ifade etmektedir. Bununla 
birlikte en genel tanımıyla yatırım; tasarruf edilen değerlere üretimde kullanılmak üzere yön verilmesi şeklinde tanımlanabilir (Sevim, U. vd., 2018: 47).

Bireysel olarak baktığımızda yatırım tasarrufların değerinin artacağı beklentisi ile altına, dövize ya da arsa, ev, araba gibi değerlere dönüştürülmesi olarak ifade edilebilir "Örneğin, işçi tasarrufunu bir bankaya yatırabilir, böylece mevduat yapmış olur ya da hazine bonosu satın alabilir veya borsada işlem gören bir şirketin paylarından satın alabilir. Risk alabilme gücü ve getiri beklentisine göre bu tasarruf sahibi bir seçim yapar. Bu seçime kişisel yatırım kararı denir" (Sancak, 2012: 5). Diğer bir deyişle nakdi sermayenin değer kaybetmemesi ve ek gelir beklentisi gibi nedenlerle yapılan faaliyetler, atıl durumda bulunan sermayenin; likiditesi yüksek olan hisse senedi, tahvil, yatırım fonu vb. finansal yatırım araçlarına veya konut, altın, gayrimenkul, arazi, vb. finansal olmayan yatırım araçlarına yatırılmasıdır denilebilir (Anbar ve Alper, 2009: 5). Gelirlerinin tamamını tüketmeyip bir kısmını da gelecek için yatırıma ayıran, piyasalarda kendi nam ve hesabına işlem yapan bireyler, bireysel yatırımcı olarak nitelendirilmektedir. Bireysel yatırımcılar, sermaye piyasasının omurgasıdır (Temizel vd., 2010: 1-20). Yatırım, "bireylerin tüketimlerini azaltarak tasarruf yolu ile varlıklarını artırmaları" ya da "tasarrufların bir mevduat karşılığında ihtiyaç duyanlara kullandırılması ya da gelecekte daha fazla tüketimde bulunabilmek amacıyla bugünkü kazançlardan vazgeçme" olarak tanımlanmaktadır (Hayta, 2008: 346-347). Bireysel yatırımcılar finansal işlemleri gerçekleştirirken amaçladıkları hedeflerden birisi sermayelerinin değer kaybetmemesidir. Finansal piyasalarda enflasyon, faiz oranları gibi değiş̧kenler yatırımcıların tasarruflarında değer kayıplarına neden olmaktadır (Usul vd., 2002: 139). Aileler içinde bulundukları yaşam dönemlerinde finansal amaçlarına göre harcamalarının mevcut düzeyine bağlı olarak bireysel ihtiyaçlarını en iyi şekilde tatmin edebilecek yatırım türünü seçmelidirler. Yatırım araçlarını seçerken özellikle likiditeyi, riski, kazancı, enflasyonu, çeşitliliği ve vergi durumunu göz önünde bulundurmalıdırlar. Aileler kısa ve uzun dönemde kar getirebilecek ve yatırımların değerini koruyabilecek yatırım alanlarını belirlemeli ve bu alanlara yatırım yapmalıdırlar (Hayta, 2008: 348).

Firmalar açısından bakıldığında firmanın karlılığına yani nihai olarak değerine katkı sağlayacak her türlü harcamalar yatırım olarak kabul edilebilir. "İşletmelerin üretim kapasitelerinde artış ya da süreklilik sağlamak amacıyla yaptıkları harcamalara işletme bilimi açısından yatırım denilmektedir" (Anbar ve Alper, 2014: 3). Firmaya göre yatırım kavramı işletme bilançosunun aktifinde yer alan varlıkların toplamı veya paranın farklı üretim unsurlarına dönüşmesidir. Yatırım ileriki dönemlerde tüketmek üzere yapılan üretim olarak da ifade edilebilir.

Türk Dil Kurumu (www.tdk.gov.tr, 2018) ekonomik yatırımı, "ekonominin veya bir ticaret kuruluşunun üretim ve hizmet gücünü artırıcı nitelikte olan aktif değerlerine yapılan yeni eklemeler" şeklinde tanımlamaktadır. Bir başka ifadeyle ekonomik anlamda yatırım "Belirli bir dönemde sermaye stokuna yapılan ilaveler" olarak açıklanabilir (Yalçıner ve Aksoy, 2011: 7). Belirli bir dönemde mevcut sermaye malları ve teçhizatı stokuna yapılan net ilaveler ekonomik yatırım olarak adlandırılır. Mevcut sermaye malları ve teçhizatı stokuna net ilave ancak, ekonomideki tasarrufların bir başka deyişle yatırıma hazır fonların yatırım harcamalarına dönüştürülmesiyle gerçekleşir (Aksoy ve Tanrı̈ven, 2007: 3). Başka bir ifadeyle ekonomik yatırım bir ülkenin üretim kapasitesine yapılan net ilavelerdir. Ekonomik yatırımın özelliği yapılan yatırımın yeni bir üretim kapasitesi yaratmasıdır. Bireysel yatırımda böyle bir șey söz konusu değildir. Sadece servetin el değiștirmesi söz konusudur. Mevcut olan bir evin sahibinin el değiştirmesi ile yeni bir üretim kapasitesi yaratılmış olmaz, sadece servet el değiştirmiş olur. Bu işlem halk arasında bireysel bir yatırım sayılırken, ekonomik anlamda bir yatırım değildir. Çünkü sadece mülkiyet el değiştirmiş̦tir. Ancak yeni bir daire yapılması ve kiraya verilmesi bir yatırım sayılabilir. Çünkü en azından burada bir hizmet kapasitesi üretilmesi söz konusudur.

Farklı yatırım kavramları açıklandıktan sonra bu çalışmada bireysel yatırımın ele alındığını ve yatırımı daha çok bu anlamda kullandığımızı belirtmek gerekir. Zira bireylerin tasarruf yapmış olmaları ve bu tasarruflarını nasıl değerlendirdiklerini ortaya koymak bu çalışmanın amacıdır. Ekonomik anlamda yatırımların yapılabilmesi için bireysel tasarrufların finansal piyasa mekanizması ile finansal sisteme sokulup yatırımlara dönüştürülmesi gerekir (Sancak, 2012: 3). Bu da öncelikle finansal yatırımlar biçiminde gerçekleşmektedir. "Bu tasarruf hiçbir şekilde finansal sisteme dahil edilmemiş ise, bu "atıl" tasarruf adını alır. Atıl, yani boşta, finansal sistemde bulunmayan tasarruf ödünç verilebilir bir fon 
değil, finansal açıdan ekonomiye katkısı olmayan bir formda duruyor demektir. Bu tür fonların sahibine bir faydası olmadığı gibi genel ekonomiye de bir faydası olmayacaktır" (Sancak, 2002: 80-81).

$\mathrm{Bu}$ araştırmada katılımcılara yatırım araçları hakkında ne düzeyde bilgiye sahip oldukları ve bu araçlara ne düzeyde yatırım yaptıkları soruldu. Bu araçlar hisse senetleri, hazine bonosu ve devlet tahvilleri, faizsiz finans kurumları, TL faiz mevduat, foreks piyasalar, repo ișlemleri, bitcoin ve benzeri sanal paralar, otomobil, gayrimenkul, döviz, altın, altın kira sertifikası, yatırım fonları, yatırım ortaklıkları ve bireysel emeklilik sistemi. Bu araçların bazıları yatırım aracı olmayıp tüketim olarak değerlendirilebilir, örneğin otomobil. Ancak dayanıklı tüketim mallarının değer kazanması bekleniyorsa bireysel yatırım olarak kabul edilebilmektedir. Çünkü bireylerin önemli bir kısmı özellikle otomobil fiyatlarının hızlı arttı̆̆ı dönemlerde otomobillere para bağlamakta, hem bu araçları kullanmakta hem de parasının değerlenmesini sağlayabilmektedir.

Bu çalışmanın amacı eğitim düzeyi olarak en üst düzeyde gelir düzeyi olarak da en azından ortalama gelirin üzerinde gelir elde eden akademisyenlerin yatırım araçlarını tanıma ve bu yatırım araçlarına yatırım yapma eğilimlerini araştırmaktır. Çalışmanın ilerleyen bölümlerinde sırasıyla literatür taraması, yatırımların önemi, tasarruflar ve finansal sistem ve analiz bölümüyle devam etmektedir. Analiz kısmı frekans analizi ve istatistiki analiz bölümlerinden oluşmaktadır.

\section{LİTERATÜR}

Araştırma konusu ile ilgili literatür incelendiğinde tasarruf, yatırım, bireysel yatırım, risk, bireysel finans, davranışsal finans konularında çok sayıda çalışmaya rastlanmaktadır. Araştırma konumuz akademisyenlerin yatırım davranışları dikkate alındığında konu ile doğrudan ilgili olan oldukça sınırlı sayıda yayına rastlanmaktadır. Dolayısıyla bu bölümde alınan literatür örnekleri asıl konu ile dolaylı olarak ilişkili kaynaklardır. Bu şekilde incelenen başlıca çalışmaların kısa özetleri aşağıda kronolojik bir şekilde sunulmaktadır.

Bernheim vd. (1997)'nin birlikte yaptıkları araştırmada Merill-Lynch adlı yatırım bankasının orta yaştaki yatırımcılarının hesap hareketlerini kullanarak yapılan çalışmalarında tasarruf ile finansal okuryazarlık arasında oldukça güçlü bir bağın olduğunu ortaya koymuşlardır. Finansal okuryazarlık arttıkça bireylerin daha fazla tasarruf ettikleri gözlemlenmiştir.

Volpe vd (2002)'nin araştırmasında online yatırımcıların yatırım okuryazarlık derecesi incelenmektedir. Araştırma, yatırımcıları yaș, eğitim, deneyim ve cinsiyetlerine göre farklı yatırım okuryazarlık derecelerine sahip olduklarını tespit etmişlerdir. Bunun yanında bayan yatırımcıların erkek yatırımcılara göre bilgi düzeylerinin daha düşük olduğunu tespit etmişlerdir.

Hilgerth vd. (2003) ABD'de bir üniversitede gerçekleștirdikleri çalışmada öğrencilerin kişisel nakit yönetimi, borçlanma, tasarruf ve yatırım konularındaki bilgi düzeyleri ve davranışları arasında anlamlı ilişkiler olduğunu ortaya koymuşlardır. Araştırma sonuçları katılımcıların borçlanma, tasarruf ve yatırım konularındaki bilgi seviyeleri arttıkça finansal davranış skorlarının da arttığını göstermektedir.

Uygur (2012) tarafından ülkemizde tasarruflar üzerinde yapılan çalışmada tasarrufların önemine vurgu yapılmış, yatırım kararları ve ekonomik büyümenin üzerinde tasarrufların oldukça önemli etkisi olduğu ifade edilmiştir. Türkiye'deki cari açığın nedeninin tasarruf yetersizliğinden kaynaklandığını ve artan özel tasarruf açığına özellikle vurgu yapılmıştır.

Gökmen (2012) araştırmasında bireylerin finansal okuryazarlık düzeyleri ile kaynaklarını daha tasarruflu ve etkin kullanarak ekonomik büyümeye katkı sağlayan tüketiciler olması arasında istatistiksel açıdan anlamlı ilişki bulmuştur.

Bayram (2004) üniversite öğrencileri üzerinde finansal okuryazarlık ve para yönetimi araştırması yapmıştır. Araştırma sonucunda öğrencilerin finansal okuryazarlık konusunda kendilerini olduğundan daha başarılı olarak algıladıkları ortaya çıkmıştır. Yazar finansal okuryazarlığın artırılması için program içeriklerinin eğitim müfredatlarında yer alması gerektiğini ifade etmektedir. 
Akbulut ve Kaderli (2009)'nin yaptıkları araştırmanın sonuçlarına göre eğitim seviyesi düşük olanlar borsayı çoğunlukla kumar yeri olarak görürken, yüksek düzeyde eğitim almış kişiler borsanın çoğunlukla yatırım yapma yeri olduğunu düşünmektedirler.

Rana vd. (2014) tarafından yapılan çalışmada eğitim seviyesi ve gelir durumunun yatırımcı kararlarını etkilediği, eğitim seviyesi ve bilgi araştırma davranışı arttıkça bireylerin daha fazla riskli yatırım yapma eğiliminin arttığı sonucuna ulaşılmıştır.

Er vd. (2014) İktisadi ve İdari Bilimler Fakültesi ve Mühendislik Fakültesi öğrencileri üzerinde gerçekleştirmiş oldukları "Lisans eğitim programlarının finansal okuryazarlık düzeylerine etkilerinin araştırılması" başlıklı çalışmalarında üniversite öğrencilerinin \% 31,7'sini yüksek, \% 30,1'ini orta, \% 16'sının ise düşük finansal okuryazarlığa sahip olduklarını belirlemişlerdir. Araştırma sonucu olarak ayrıca üniversite öğrencilerinin eğitim alanları ile (Mühendislik ve İktisadi ve İdari Bilimler) finansal okuryazarlık düzeyleri arasında anlamlı ilişki tespit edilmiştir. Çalışmada OECD’nin finansal okuryazarlığı belirleme ölçeği kullanılmıștır.

Gutnu ve Cihangir (2015) Osmaniye Korkutata Üniversitesi personeli üzerinde uygulamış oldukları anket ile yapılan çalışmasında söz konusu personelin ağırlıklı olarak finans konularını ailelerinden öğrendikleri ifade edilmiş, ancak personelin güncel finans konularıyla da ilgilendikleri ortaya çıkmıştır.

Pirgaip (2016) çalışmasında altına yapılan doğrudan yatırımlarla altına borsa yoluyla yatırım yapılması arasındaki performansı analiz etmiştir. Araştırma sonucunda uzun vadede, sirasıyla altın ve altın borsa yatırım fonlarının, ekonomik şartların olumlu seyrettiği dönemlerde ise altın yatırım fonları ve altına endeksli yatırım fonlarının bir altın yatırımcısı için daha uygun yatırım alternatiflerini teşkil ettiği sonucuna ulaşılmıştır.

Doğan vd. (2016) yatırımcıların kişilik ve demografik özellikleri ile yatırım kararları, risk algıları arasındaki ilişkileri araştırmak amacıyla yaptıkları çalışmada Hatay, Kocaeli, Denizli, Eskişehir, Aydın ve Mersin illerinde faaliyet gösteren bankaların 268 personeline anket uygulamışlar ve analiz sonucunda yatırım tercihlerinin demografik özelliklerine göre değiștiğini tespit etmişlerdir. Araştırmada en çok tercih edilen yatırım araçları sırayla banka mevduatı, altın, döviz, hisse senedi ve diğer şeklinde sıralanmıștır.

Danışman vd. (2016) tarafından yapılan araştırmada 390 İktisadi ve İdari Bilimler Fakültesi öğrencisinin finansal okuryazarlık durumu araştırılmış ve öğrencilerin temel düzeyde finansal okuryazar olduğu ama ileri düzeyde finansal okuryazar olmadıkları sonucuna ulaşılmıştır.

Ece (2017) araştırmasında bireysel yatırımların özelliklerinin ve yatırım bilgilerinin onların yatırım davranışları üzerindeki etkisini ve hangi tip yatırımcının ne tür yatırım aracını tercih ettiğini ortaya koymaya çalışmıștır. Bartın ilinde bireysel yatırımcılara anket uygulanmış ve anket verilerini Ki-Kare testi ile analize tabi tutmuştur. Araştırmada katılımcıların cinsiyet, yaş ve medeni durumu ve yatırım tercihlerini etkilemediği, ancak eğitim durumu ve yatırım bilgisinin yatırım tercihlerini etkilediği görülmüştür.

Timur (2018), Mersin Üniversitesi öğrencileri üzerinde yapmış olduğu finansal okuryazarlık araştırmasında öğrencilerin finansal okuryazarlık durumlarının düşük olduğu sonucuna ulaşmıştır. Bu araștırmada öğrencilerin finansla ilgili konuları genellikle ailelerinden öğrendikleri ve finansal gelişmeleri daha çok televizyon ve internet üzerinden izledikleri bu işlemi ortalama olarak haftada bir kez yaptıkları sonucuna ulaşılmıștır. Araștırmanın istatistiki sonucu olarak yaş ve sınıf değişkenleri ile finansal gelişmelerin takip edilme sıklı̆ğ ve finansal kavramların belirlilik düzeyleri arasında anlamlı ilişkinin bulunduğu sonucuna ulaşılmıştır.

\subsection{Yatırımların Önemi, Tasarruflar ve Finansal Sistem}

Aileler çok değişik amaçlarla tasarrufta bulunurlar. Ailelerin tasarruflarını kendilerine düzenli ve sürekli gelir getirecek bir şekilde değerlendirme şekillerine yatırım adı verilmektedir (Yazıcıoğlu ve Erdoğan, 2004: 198). Bir ailenin yatırımlarını değerlendirebileceği yatırım araçlarını iki ayrı gruba ayırarak incelemek mümkündür. Bunlar; ev, arsa, bina gibi gayrimenkul yatırım araçları ve banka mevduatı, altın, döviz, hazine bonosu, fon gibi menkul yatırım araçlarıdır (Yazıcıoğlu ve Erdoğan, 2004: 200). Bireysel yatırımların önemli bir kısmı sadece bir el değiştirme şeklinde olurken bunların 
bazıları da finansal sisteme girmek suretiyle firmalara finansman kaynağına dolayısıyla ekonomik yatırımlara dönüşmektedir.

Tasarrufun ekonomi literatüründe anlam kazanması ancak ekonomik faaliyetler sürecinde aktif olarak sisteme dahil olması ile mümkündür. Tasarruflar finansal sisteme para piyasaları ve sermaye piyasaları ile girer. Yatırımların finansman ihtiyacı tasarrufların sistem aracılığıyla şirketlere finansman sağlaması ile gerçekleşir. Bu şekilde hem bireylerin tasarrufları bireysel yatırımlar olarak değerlenir ve tasarruf sahibi bireylerin refah düzeyi artar hem de ülkenin ihtiyaç duyduğu yatırımlara finansman sağlanmış olur.

Şirketlerin kısa vadeli finansman ihtiyacı genellikle bankalar tarafından karşılanırken, uzun vadeli finansman ihtiyacı da sermaye piyasalarından sağlanmaktadır. Ülkemizde olduğu gibi henüz yeterince gelişmemiş olan sermaye piyasalarının daha fazla gelişmesi ve şirketlerin ihtiyacı olan uzun vadeli fonların sağlanabilmesi için bireysel yatırımların sisteme girişinin sağlanması kritik önem taşımaktadır. Bireysel tasarrufların önemi burada yatmaktadır. Bireyin yatırım davranışları sermaye piyasalarının gelişimini doğrudan etkileyecek ve bu hem bireyin hem ülke ekonomisinin dolayısıyla sonuçta yine bireylerin refahına katkı sağlayacaktır.

Finansal sistem, tasarrufların yatırım harcamalarında kullanılmak üzere şirketler sektörüne yönlendirilmesini sağlamakta ve kaynakların mümkün olan en verimli alanlara yönelmesi, şirketlerin karşı karşıya olduğu risklerin azaltılması ve şirketlere likidite sağlanması yoluyla bir ekonominin üretim kapasitesindeki artışın etkin bir biçimde gerçekleştirilmesine katkıda bulunmaktadır (TCMB, 2015: 7).

Ekonomik yatırımların finansmanı özellikle tasarruf-yatırım açı̆̆ı olan ülkelerde daha büyük önem taşımaktadır. Çünkü bir taraftan artan nüfus ve ekonomik kalkınmanın hızlandırılması için belli düzeyde yatırım gerekirken diğer taraftan ülkenin tasarruflarının yatırımlar için yeterli olmaması halinde fark dışarıdan borçlanma suretiyle karşılanmaktadır. "Türkiye'de yatırımların önemli bir bölümü çoğunlukla kısa vadeli dış tasarruflarla finanse edilmiştir. Dış tasarruflara bağımlılık ise küresel bir kriz durumunda Türkiye'nin sermaye çıkışı riskine maruz kalmasına neden olmuştur. Bu ekonomik büyüme üzerinde olumsuz etki yapmıştır (Sancak ve Demirci, 2012: 185). Dışarıdan borç bulmanın da çeşitli sorunları olduğu bilinmektedir. Dolayısıyla mevcut tasarrufların en uygun şekilde değerlendirilmesi ve tasarruf-yatırım açığının neden olduğu dışa bağımlılığı en aza indirmek hedeflenmektedir. "Ekonomik büyümeyi finanse etmesi için tasarrufların etkin şekilde yatırımlara kanalize edilme mekanizmalarının kurulması gerekir. Özellikle tasarrufların ekonomiye yönlendirilmesi için toplumu iyi seviyede bilgilendirilmesi, yatırım yapmanın bazı risklerinden dolayı ortaya çıkan korkuların giderilmesi gereklidir (Sancak ve Demirci, 2012: 187).

Bireysel tasarruf sahiplerinin tasarruflarını yatırımlara dönüştürmek ve mümkün olan en iyi getiriyi en uygun riskle elde etme konusunda belli düzeyde finansal okuryazarlığa sahip olmaları gerekir. Bu araştırmada katılımcıların verdikleri cevaplara göre yatırım araçları hakkında ne düzeyde bilgi sahibi oldukları ortaya çıkacak ve katılımclların finansal okuryazarlık düzeyi hakkında bazı sonuçlara ulaşılabilecektir. Finansal okuryazarlığı en temel anlamda bireylerin tasarruflarını yönetebilmeleri için yeterli mali bilgiye sahip olmaları, kişisel borç ve kredilerini yönetebilmeleri, kısa ve uzun vadede yatırımlarını değerlendirebilmeleri olarak tanımlayan çalışmalar vardır (Wagland, 2006). Finansal okuryazarlık, bireylerin yatırım araçları ve yatırım kuralları hakkında yeterli bilgiye sahip olması, bilinçli yatırım yapabilme ve finansal kararları yeterli bilgiye dayanarak alabilme anlamı taşır. Finansal okuryazarlık düzeyi yüksek bir kişi, yatırımlarında sağlıklı karar verebilecek bir bilgi birikimi ve yatırım bilincine sahip bir birey olarak kabul edilir (Sancak, 2016: 70). Toplum açısından ele alındığında, öncelikle finansal okuryazarlık sayesinde bireylerin tasarrufa yöneltilmesi, tasarruflarını ekonomik gelişme için kullanılabilir olmasından söz etmek gerekir (Atkinson ve Messy, 2013). Tüketicilerin finansal karar verme sürecinde daha düşük finansal okuryazarlığa sahip olması daha düşük hisse senedi yatırımına yol açmaktadır (Rooij vd.: 2011, 449). Finansal okuryazarlık, insanların kendi yararına önemli finansal kararlar almak için ne bilmesi gerektiğidir (Mandell, 2006: 1). Bireylerin finansal okuryazarlık düzeylerine bağlı olarak verecekleri yatırım kararları ekonomide kaynakların tahsisini etkiler. Sonuçta reel ekonomiye aktarılacak kaynaklar da ülkenin uzun dönem 
büyüme potansiyelini belirler (Widdowson ve Hailwood, 2007: 37-38). Finansal okuryazarlığın artırılabilmesi için bireylerin finansal olarak eğitilmesi gerekir.

Bireylerin finansal okuryazarlık durumuna bakıldığında ülkemizde ve diğer ülkelerde finansal okuryazarlık konusunda önemli yetersizlikler olduğu görülmektedir. Yapılan çeşitli araştırmalar bu görüşü doğrulamaktadır. Örneğin, ABD’de yapılan bir araştırmada öğrencilerin finansal okuryazarlık düzeyinin yeterli düzeyde olmadığı ortaya çlkmıştır. Bulgular birçok öğrencinin para kazanma, harcama, tasarruf ve yatırıma dair temel finans ilkelerini anlamadığını göstermektedir (Gökmen, 2012: 55-57). TEB (2015) tarafından yapılan bir araştırmada Macaristan, Türkiye ve Estonya gibi ülkelerde tasarruf ve yatırım yapma oranı çok düşük kalırken borçlanma oranının tam tersine yüksek olduğu görülmektedir. Aynı araştırmada Arnavutluk'ta \% 31, Türkiye'de \% 30, Peru'da \% 27 ve Güney Afrika'da \% 26 oranında katılımcının gelirleri giderlerini karşılamadığı için borçlanmaya başvurdukları ortaya çıkmıştır (TEB, 2015: 6). TCMB (2011) tarafından yapılan bir araştırmada Türkiye'de finansal sistemin dışında kalan yetişkinlerin oranı \% 51 iken bu oran Hollanda'da \% 0, Almanya'da \% 3 ve İngiltere'de \% 9'dur. Dolayısıyla ekonomik büyüme için sistem dışındaki fonlar sisteme kazandırılmalıdır (TCMB, 2011. 1). Örneğin; altın ekonomik faaliyetler zincirine dahil olmuyorsa ekonomi bilimi açısından tasarruf olarak değerlendirilmemektedir (Sancak ve Demirci, 2012: 162). Bununla birlikte ülke ekonomisindeki kırılganlık ve finansal piyasalardaki belirsizlik karşısında altına olan talebin gün geçtikçe artması (Pirgaip, 2006: 10) tasarrufların finansal sistemin dışına kaymasına neden olmaktadır. Mülkiyetin el değiştirmesi de üretime ek katkı sağlamadığı için yatırım olmamaktadır. Hisse senetlerinin ilk elden ihracında şirket sermayesine katkı olduğu için ilk elden hisse senedi alınması bir yatırım olarak değerlendirilebilirken, ikincil piyasada hisselerin el değiştirmesi ekonomik anlamda yatırım olarak kabul edilmemektedir. Çünkü burada sisteme bir fon girişi olmamaktadır.

\section{ARAŞTIRMA}

\subsection{Araştırmanın Amacı}

Araştırmanın amacı toplumumuzda eğitim düzeyi açısından üst kesimde ve gelir düzeyi olarak da ortalamaya göre daha iyi bir düzeyde yer alan akademisyenlerin tasarruflarını değerlendirme ve yatırım araçlarına ilgisi ve yatırım yapma konusundaki tutumlarını belirlemektir. Ülke olarak bulunduğumuz gelişmekte olan ülkeler grubunun genel bir sorunu olan tasarruf yatırım açığı sorunu dikkate alındığında zaten yetersiz olan tasarrufların oldukça yüksek verimlilikte değerlendirilmesi kritik önem taşımaktadır. Gerek eğitim, gerekse gelir düzeyi dikkate alındığında akademisyenlerde tasarruf-yatırım bilincinin yeterince gelişmiş olması beklenmektedir. Dolayısıyla çalışmanın amacı akademisyenlerin tasarruflarını ekonomik anlamda değerlendirme düzeylerinin yani yatırım eğilimlerinin araştırılması şeklinde belirlenebilir.

\subsection{Araştırmanın Yöntemi}

$\mathrm{Bu}$ çalışmada örnekleme yöntemi olarak tesadüfi olmayan örnekleme yöntemlerinden kolayda örnekleme yöntemi kullanılmıştır. Bu örneklem yönteminde, örnek sayısı ve örnek içinde yer alan elemanlar istatistiksel olarak tesadüfi olmayan yollarla belirlenir (Robson, C. 2002). Çoğunlukla keşif amaçlı araştırmalarda kullanılır, hipotez üretmeyi sağlar. Örneğin temsil kapasitesi tam olarak bilinmez. Uygulanması kolay, çabuk ve az masraflıdır. Çalışmanın akademisyenlerin yatırım eğilimlerini tespit etmeye yönelik mevcut durumu tespit etmeyi amaçlamasından ötürü betimleyici (tasvir edici - descriptive) ve keşifsel (explorative) özellikte bir araştırma olduğu söylenebilir.

\subsection{Araştırmanın Evreni, Örneklemi ve Anket Formu}

Araştırmada veri toplama aracı olarak internet üzerinden anket uygulaması yapılmıştır. Uygulanan anket formu araştırmacı tarafından geliştirilmiştir. Araştırmanın ana kütlesi Türkiye'de üniversitelerde çalışan akademik personeldir. Akademik personele 2018 yll Nisan-Mayıs döneminde anket uygulanmıștır. Anket uygulaması, Türkiye'nin farklı bölgelerinde faaliyette bulunan 30 devlet üniversitesi öğretim üyelerine ve öğretim elemanlarına internet üzerinden anket linki gönderilerek yapılmıştır. Dönüşü artırmak için formlar kişilerin e-posta adreslerine kendi isimlerine hitaben yazılarak gönderilmiş, toplu gönderimlerden kaçınılmış, ayrıca anket gönderildikten sonra da telefonla 
görüşmek suretiyle geri dönüşün artırılmasına çalışılmıştır. Bu araştırmada uygulanan ankette 653 akademisyenin dönüşü sağlanmıştır. Gizlilik ilkesinden dolayı anketi dolduranların üniversiteleri belli olmadığından verilerin değerlendirilmesinde üniversite ayrımı yapılmamış sonuçlar toplu değerlendirilmiştir.

Türkiye'deki üniversitelerde çalışan akademisyen sayısı 2018 yılı itibariyle 158 098'dir (www.aa.com.tr; E.T. 30.11.2018). Evren büyüklügü 100.000 'i aşan ana kütlelerde $( \pm 0,05$ örnekleme hata payı ile) 384 kişilik örneklem sayısı yeterli görülmektedir (Yazıcıoğlu ve Erdoğan, 2004: 50). Soru gruplarına göre ankette yer alan sorular, demografik sorular (10), Yatırım araçları ile ilgili soruları (15), borsaya yatırım yapma ile ilgili sorular (6) olmak üzere toplam 31 sorudan oluşmaktadır.

\subsection{Verilerin Analizi}

Araștırmadan elde edilen veriler önce frekans analizine tabi tutulmuş ve daha sonra da istatistiksel olarak farklılık testi yapılmıştır. Sonuçlar tablo ve grafikler halinde sunulmuş ve yorumlanmıştır. Sorular üç gruptan oluşmaktadır. Birinci grup demografik sorular, ikinci grup yatırım araçlarını tanıma ve yatırım yapma durumları ile ilgili sorular ve üçüncü grup ise borsaya yatırım yapma ile ilgili sorulardan oluşmaktadır.

\subsection{Verilerin Frekans Analizi}

Bu kısımda araştırmadan elde edilen veriler frekans analizine tabi tutulmuş, tablolar halinde sunulmuş ve sonuçlar yorumlanmıştır.

Tablo 1a: Demografik Özellikler

\begin{tabular}{|c|c|c|c|c|c|}
\hline \multicolumn{3}{|c|}{ Cinsiyetiniz } & \multicolumn{3}{|c|}{ Medeni Durumunuz } \\
\hline Seçenekler & $\begin{array}{l}\text { Sayı } \\
\end{array}$ & $\begin{array}{l}\text { Yüzde (\%) } \\
\end{array}$ & Peçenekler & $\overline{~ S a y ı}$ & Yüzde (\%) \\
\hline Erkek & 455 & 69.68 & Evli & 531 & 81.32 \\
\hline Kadın & 198 & 30.32 & Bekar & 1117 & 17.92 \\
\hline \multicolumn{3}{|c|}{ Aile Bireyleri Sayısı } & Diğer & 5 & 0.76 \\
\hline Seçenekler & Sayı & Yüzde (\%) & \multicolumn{3}{|c|}{ Oturduğunuz ev } \\
\hline 1-2 Kişi & 177 & 27.11 & Seçenekler & Sayı & Yüzde (\%) \\
\hline 3-4 Kiși & 387 & 59.26 & Kira & 229 & 35.07 \\
\hline 5-6 Kişi & 86 & 13.17 & Lojman & 98 & 15.01 \\
\hline Daha fazla & 3 & 0.46 & Mülk & 326 & 499.92 \\
\hline
\end{tabular}

Tablo 1a'da yer alan demografik özellikler incelendiğinde anketi cevaplandıran akademisyenlerin \% 69,68'i erkek, \% 30,32'si kadındır. Katılımcıların \% 81,32'si evli, \% 18,92'si bekar olduğunu ifade etmiştir. Aile bireyleri sayısı açısından bakıldığında \% 27,11'i 1-2 kişilik bir ailede, \% 59,26'sı 3-4 kişilik ailede, \% 13,17'si ise 5-6 kişilik ailede, \% 0,46'sı ise daha kalabalık bir ailede yaşamaktadır. Katılımcıların \% 49,92'si kendi evinde ikamet ederken, \% 35,07'si kirada oturmakta, \% 15,01'i de lojmanda oturduğunu beyan etmiștir. Tablo 1b'de alan itibariyle bakıldığında akademisyenlerin \% 57,27'si Sosyal Bilimler alanında, \% 16,39’u Fen Bilimleri alanında, \% 13,32'si Sağlık Bilimleri alanında, \% 9,80'i Mühendislik alanında ve \% 3,2'si de diğer alanlarda çalışmaktadır. Ankete cevap veren akademisyenlerin \% 42,57'si Arş. Gör., Öğr. Gör., ya da Okt. kadrosunda, \% 26,95'i Dr. Öğr. Üyesi kadrosunda, \% 15,01'i doçent kadrosunda ve \% 15,47'si de Profesör kadrosunda görev yapmaktadır. Üniversitede çalışılan hizmet süresi olarak bakıldığında da \% 29,25 1-5 yıl arasında, \% 27,41 6-10 yl arasinda, \% 10,41 11-15 yıl arasında, \% 11,18 16-20 yıl arasinda faaliyette bulunurken, \% 21,75 oranında akademisyenin hizmeti 21 yılın üzerindedir. Yaş itibariyle bakıldığında da anketi dolduran akademisyenlerin \% 8,58'i 20-29 yaş arasında, \% 45,48'i 3039 yaş arasında, \% 25,88'i 40-49 yaş arasında, \% 16,53'ü 50-60 yaş arasında ve \% 53'ü de 60 yaş ve üzerindedir. 
Tablo 1b: Demografik Özelliklerin Devamı

\begin{tabular}{|c|c|c|c|c|c|}
\hline \multicolumn{3}{|c|}{ Bilim alanınız } & \multicolumn{3}{|c|}{ Ünvanınız } \\
\hline Seçenekler & Sayı & Yüzde (\%) & Seçenekler & Sayı & Yüzde (\%) \\
\hline Sosyal Bilimler & 374 & 57.27 & $\begin{array}{l}\text { Arş. Gör.-Okt.-Öğr. } \\
\text { Gör. }\end{array}$ & 278 & 42.57 \\
\hline Fen Bilimleri & 107 & 16.39 & $\begin{array}{l}\text { Yardımcı Doçent } \\
\text { Dr. }\end{array}$ & 176 & 26.95 \\
\hline Sağlık Bilimleri & 87 & 13.32 & Doçent Dr. & 98 & 15.01 \\
\hline $\begin{array}{l}\text { Mühendislik } \\
\text { Bilimleri } \\
\end{array}$ & 64 & 9.80 & Profesör Dr. & 101 & 15.47 \\
\hline Diğer & 21 & 3.22 & & & \\
\hline \multicolumn{3}{|c|}{ Üniversitedeki hizmet süreniz } & \multicolumn{3}{|c|}{ Yaşınız } \\
\hline Seçenekler & Sayı & Yüzde (\%) & Seçenekler & Frekans & Yüzde (\%) \\
\hline $1-5 \mathrm{yll}$ & 191 & 29.25 & $20-29$ & 56 & 8,58 \\
\hline 6-10 yil & 179 & 27.41 & $30-39$ & 297 & 45,48 \\
\hline $11-15$ yıl & 68 & 10.41 & $40-49$ & 169 & 25,88 \\
\hline $16-20 \mathrm{yll}$ & 73 & 11.18 & $50-59$ & 108 & 16,53 \\
\hline $21+$ & 142 & 21.75 & $60-69$ & 23 & 3,53 \\
\hline \multicolumn{3}{|c|}{ Aylık Gelir Düzeyi } & \multicolumn{3}{|c|}{ Aylık Tasarruf Miktarı } \\
\hline Seçenekler & Sayı & Yüzde & Seçenekler & Sayı & Yüzde \\
\hline $3.000-4.500$ & 15 & 2.30 & 500 TL den az & 174 & 26.65 \\
\hline $4.500-6.000$ & 261 & 39.97 & \begin{tabular}{|l|}
$500-1.500$ TL arası \\
\end{tabular} & 180 & 27.57 \\
\hline $6.000-7.500$ & 141 & 21.59 & $\begin{array}{c}1.500-3.000 \mathrm{TL} \\
\text { arası } \\
\end{array}$ & 182 & 27.87 \\
\hline $7.500-9.000$ & 98 & 15.01 & 3.000 TL den fazla & 117 & 17.92 \\
\hline $9.000+$ & 138 & 21.13 & & & \\
\hline
\end{tabular}

Aşağıda akademisyenlerin yatırım araçlarını tanıma ve yatırım yapma durumları ile ilgili cevapları tablolar halinde değerlendirilerek sunulmuştur. Cevap seçeneklerinin anlamları, Yatırım aracını tanıma açısından:

1. Hiç tanımıyorum, 2. Tanımıyorum, 3. Kısmen Tanıyorum, 4. Tanıyorum, 5. Çok iyi taniyorum.

Yatırım araçlarına yatırım yapma açısından ise

1. Hiç yatırım yapmıyorum, 2.Yatırım yapmıyorum,3.Kısmen yapıyorum,4.Yatırım Yapıyorum,5. Çok sık yatırım yapıyorum, şeklinde belirlenmiştir.

Grafik 1: Akademisyenlerin Hisse Senetlerini Tanıma ve Yatırım Yapma Durumu

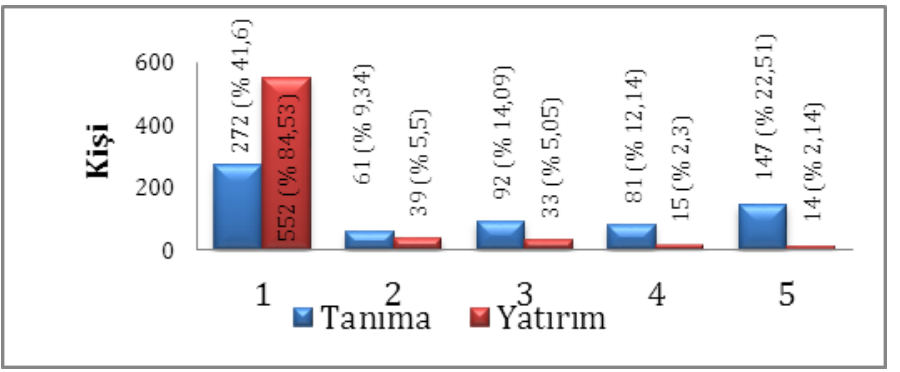

Hisse senetlerine yatırım şirketlerin öz kaynak sağlaması açısından önemlidir. Grafik 1'deki verilere bakıldığında ankete cevap veren akademisyenlerin \% 50'den fazlası hisse senetleri hakkında bilgisi olmadığını ya da hiç bilgisi olmadığını ifade etmiştir. Çok iyi bilgiye sahibim diyenlerin oranı ise \% 22.51'dir. Yatırım yapma olarak bakıldığında ise \% 84.53 sıfır düzeyinde yatırım yaparken, \% 2,14'lük bir oranda akademisyenin çok sık yatırım yaptı̆̆ı, yatırım yapıyorum seçeneği ile birleştirildiğinde ise \% 4.44 oranında akademisyenin hisse senetlerine yatırım yaptığı anlaşılmaktadır. Akademisyenlerin "yatırım yapma" düzeyi "hisse senetlerini tanıma" ile kıyaslandığında oldukça düşük düzeyde bulunmaktadır. Buradan akademisyenlerin hisse senetlerini tanıdıkları halde çeşitli nedenlerle yatırım yapmaktan kaçındıkları sonucu çıkartılabilir. Bunun nedenleri muhtemelen riskten kaçınma ve yatırım analizi konusundaki yetersizlikler olabilir.

\section{R\&S}

Research Studies Anatolia Journal

Volume: 2, Issue:4, January 2019 
Grafik 2. Akademisyenlerin Hazine Bonosu ve Devlet Tahvillerini Tanıma ve Yatırım Yapma Durumu

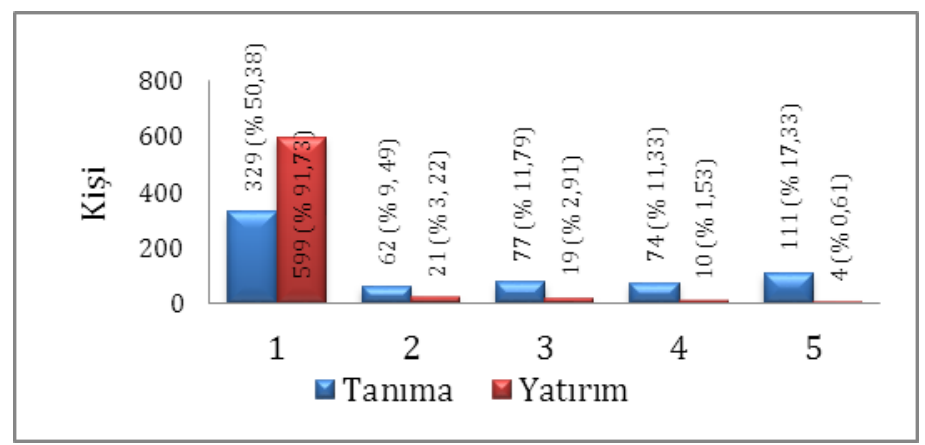

Hazine bonosu ve devlet tahvili devletin kısa ve uzun vadeli finansman ihtiyacını karşılamak amacıyla ihraç ettiği sabit faiz getirili yatırım araçlarıdır. Grafik 2'de bu araçlara yatırım yapıp yapmadıkları sorusuna sadece \% 2,14 oranında akademisyen bu araçlara yatırım yaptıklarını ya da çok sık yatırım yaptıklarını belirtmiştir. Oldukça düşük yatırım oranlarının gösterdiği sonuç akademisyenlerin bu tür araçlara da fazla ilgi duymadığıdır. Bunun de muhtemel sebepleri faizden kaçınma ya da faizlerin reel anlamda yeterli getiri sağlamadığı düşüncesi olabilir.

Grafik 3. Akademisyenlerin Faizsiz Finans Kurumlarını Tanıma ve Yatırım Yapma Durumu

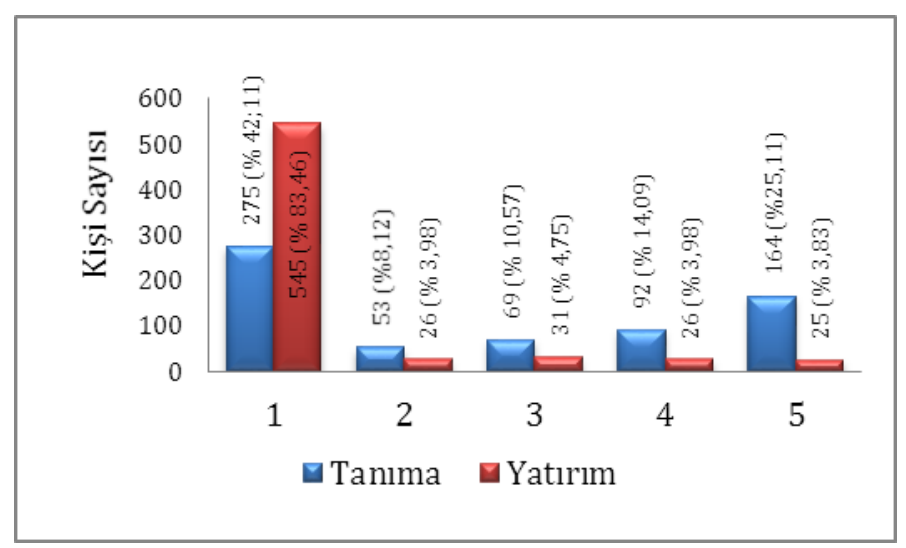

Faizsiz finans kurumları kar zarar ortaklığ (riskin paylașılması) esasına göre faaliyette bulunan finans kuruluşlarıdır. Bu soruda akademisyenlerin "faizsiz finans kurumları hakkında ne düzeyde bilgi sahibi oldukları" sorulmuş ve alınan cevaplar Grafik 3'te frekans ve yüzde olarak gösterilmiştir. Akademisyenlerin tasarruflarını bu kuruluşlarda değerlendirme oranı \% 7,81'dir. Hisse senetleri ve bono ve tahvillere kiyasla bu kurumlara daha fazla yatırım yapıldığı görülmekle birlikte oran yine de oldukça düşüktür. Faize yatırıma göre daha yüksek olmakla birlikte tasarrufların bu kurumlara yatırılma oranı düşük çıkmıştır. Bunun olası nedenleri reel anlamda getirinin tatmin edici olmaması ve halk arasında bu kurumların da çalışma sisteminin faiz sistemiyle çalışan bankalarla faiz kelimesinin kullanılmaması dışında bir farklılık olmadığı düşüncesi ve kanaati olabilir.

Grafik 4. Akademisyenlerin Faizli Enstrümanları Tanıma ve Yatırım Yapma Durumu

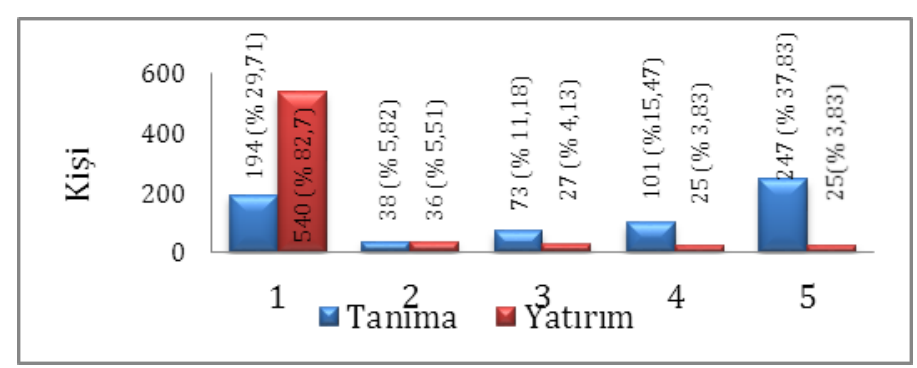

Faiz sabit getirili risksiz bir yatırım aracıdır. Grafik 4'te akademisyenlerin "faizli yatırım araçlarını ne kadar tanıdıkları" ve "bu araçlara ne kadar yatırım yaptıkları" sorulmuş ve alınan cevaplar frekans ve yüzde olarak verilmiştir. Katılımclların \% 88,21'i hiç yatırım yapmadıklarını ya da yatırım yapmadıklarını, \% 7,66 ise yatırım yaptıklarını ya da çok sık yatırım yaptıklarını ifade etmişlerdir. Sonuç faizsiz finans kuruluşlarına yapılan yatırım oranı ile benzerlik göstermektedir. Akademisyenlerin bir yatırım aracı olarak devlet tahvili ve hazine bonosuna ilgilerinin düşük düzeyde olduğu belirtilebilir. 
Grafik 5. Akademisyenlerin Foreks Piyasaları Tanıma ve Yatırım Yapma Durumu

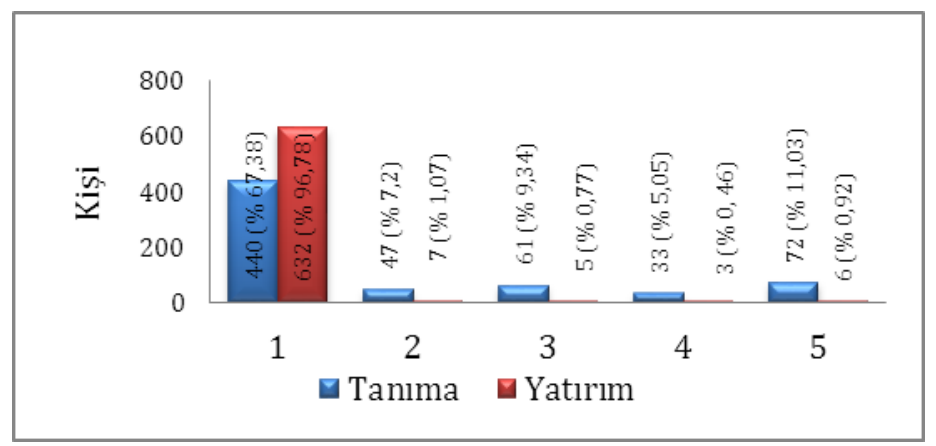

Foreks piyasalar özetle kaldıraçlı döviz alım satım işlemleri olup 24 saat boyunca işlem yapılabilen uluslararası entegre piyasalardır. Foreks piyasalarla ilgili soruya verilen cevapların istatistikleri Grafik 5'te görülmektedir. Ankete katılan akademisyenlerin verdikleri cevaplara göre \% 74.58 oranında akademisyen foreks piyasalarını tanımadığını ya da hiç tanımadığını belirtirken, \% 16,08 oranında akademisyen bu piyasaları tanıdığını ya da çok iyi tanıdı̆̆ını belirtmiştir. Yatırım açısından bakıldığında ise foreks piyasalara yatırım yapan ya da çok sık yatırım yapan akademisyen oranı sadece \% 1,38'dir. \% 97,85 oranında akademisyen foreks piyasaları tanımadığını ya da hiç tanımadığını ifade etmiştir.

Grafik 6. Akademisyenlerin Repoyu Tanıma ve Yatırım Yapma Durumu

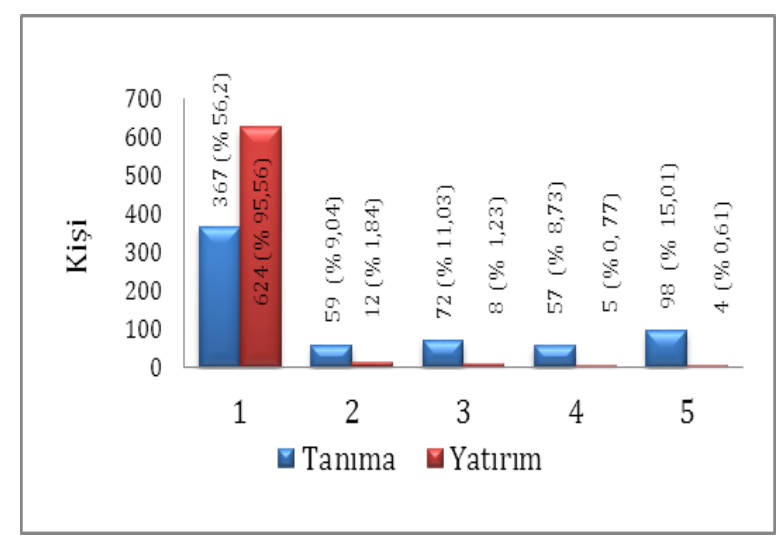

Repo basit bir ifadeyle nakit fazlasının kısa süreli olarak faiz geliri elde etmek amacıyla yatırılmasını ifade etmektedir. Grafik 6'da akademisyenlerin "repo işlemlerini tanıma" ve "repoya yatırım yapma" durumları ile ilgili soruya verdikleri cevapların dökümü yer almaktadır. "Repoya yatırım yapma" açısından bakıldığında ise \% 97,4 oranında akademisyen repoya hiç yatırım yapmadığını ya da yatırım yapmadığını belirtmiş, sadece \% 1,38 oranında akademisyen repoyu yatırım yaptığını açıklamıștır. Faiz temelli yatırım seçeneklerindeki gerekçeler repo için de söylenebilir.

Grafik 7. Akademisyenlerin Sanal Paraları Tanıma ve Yatırım Yapma Durumu

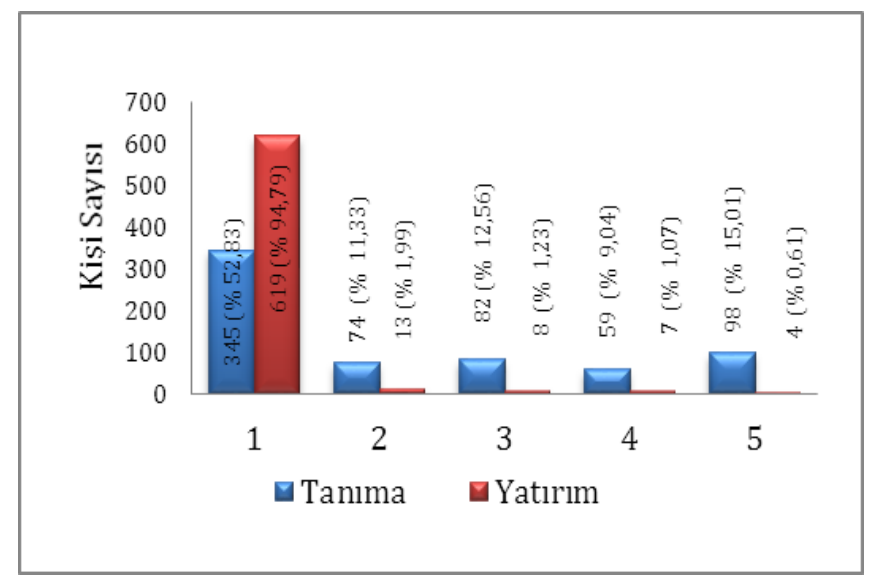

Son zamanlarda ortaya çıkan yeni bir yatırım seçeneği ise Bitcoin ve benzeri sanal paralar olmuş ve bu alanda paralarını değerlendirmek isteyen yatırımcılar ortaya çıkmıştır. Çünkü Bitcoin oldukça yüksek primler yapmıştır. "Bitcoin'i tanıma" ve "yatırım yapma düzeyi" oldukça düșüktür. Grafik 7'deki verileri göre yatırım açısından baktığımızda sadece \% 1,99 oranında akademisyenin sanal paralara yatırım yaptığını ya da çok sık yatırım yaptığı belirtilebilir. Yeni olması, çok bilinmemesi ve oldukça riskli olması bu yatırım aracından uzak durulmasının nedenleri arasında olabilir. 
Grafik 8. Akademisyenlerin Otomobili Tanıma ve Yatırım Yapma Durumu

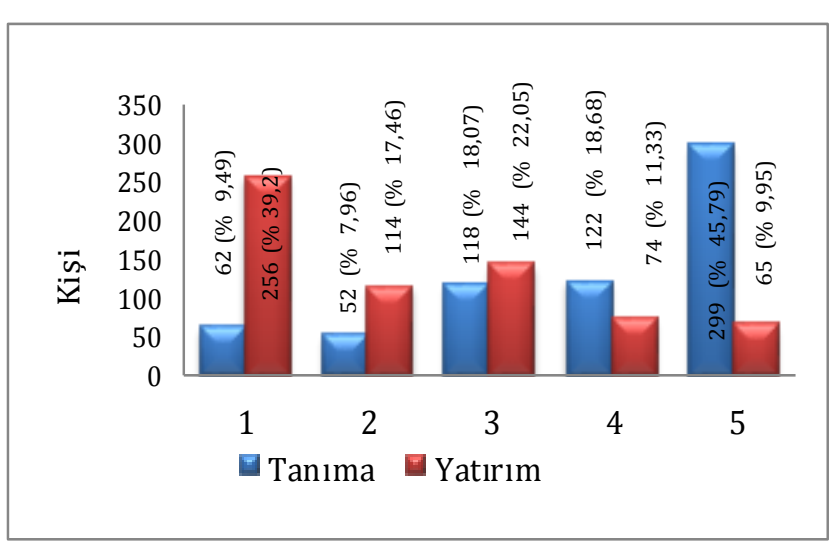

Otomobil zaman zaman yapılan tasarrufların yatırıldığı bir araç olarak görülmektedir. Otomobil yatırımları hakkında sorulduğunda akademisyenlerin verdikleri cevapların dökümü Grafik 8'de yer almaktadır. Yatırım yapma açısında bakıldığında ise \% 56,66'sı yatırım yapmadığını ya da hiç yapmadığını \% 21,28 ise yatırım yaptığını ya da çok sık yatırım yaptığını belirtmiştir. Bundan önce sorulan yatırım araçlarında yatırım oranları oldukça düşükken otomobile yatırım yapıyorum diyenlerin oranı daha yüksektir. Otomobil binek olarak kullanılırken aynı zamanda değerini koruduğu ve artırdığı için tasarrufların değerlendirildiği ve zorunlu tasarruf yapılan bir araç olarak da görülmektedir.

Grafik 9. Akademisyenlerin Gayrimenkulleri Tanıma ve Yatırım Yapma Durumu

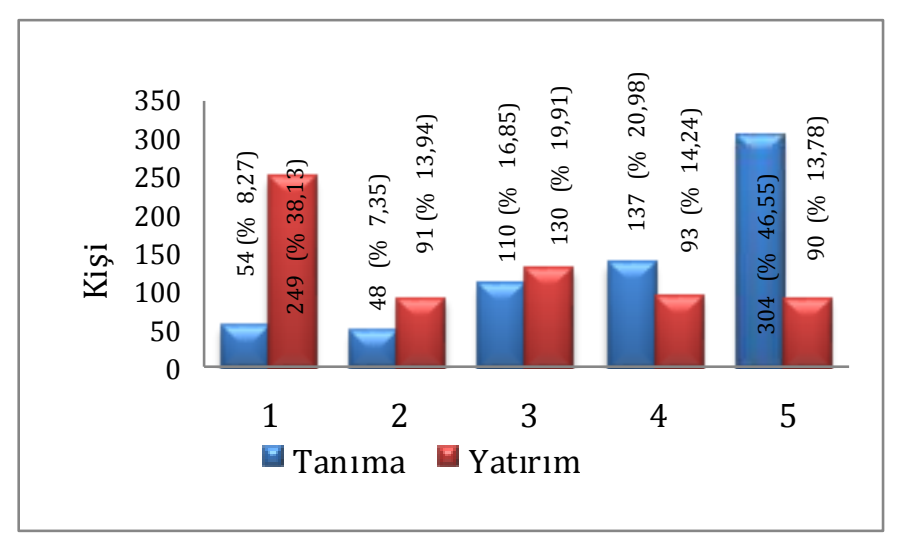

Gayrimenkul ülkemizde klasik bir yatırım türüdür. Akademisyenlerin yatırım aracı olarak "gayrimenkulleri tanıma" yüzdeleri ile "yatırım yapma durumları" Grafik 9'da görülmektedir. Ankete katılan akademisyenlerin gayrimenkulleri çok iyi tanıdıklarını ya da tanıdıklarını ifade edenlerin oranı ise \% 67,53'tür. Gayrimenkule yatırım yaparım ya da çok sık yatırım yaparım diyenlerin oranı \% 28,02 iken hiç yatırım yapmam ya da yatırım yapmam diyenlerin oranı ise \% 52,07 olarak bulunmuştur. Şu ana kadar olan yatırım araçları içerisinde en yüksek yatırım tercihi gayrimenkullerden yana görünmektedir. Ülkemizde konut ihtiyacının devam etmesi ve konuta olan talebin devamlı olması gayrimenkullerin fiyatını da yükselttiği için bu alanda yatırım oranı daha yüksek çıkmıştır.

Grafik 10. Akademisyenlerin Dövizleri Tanıma ve Yatırım Yapma Durumu

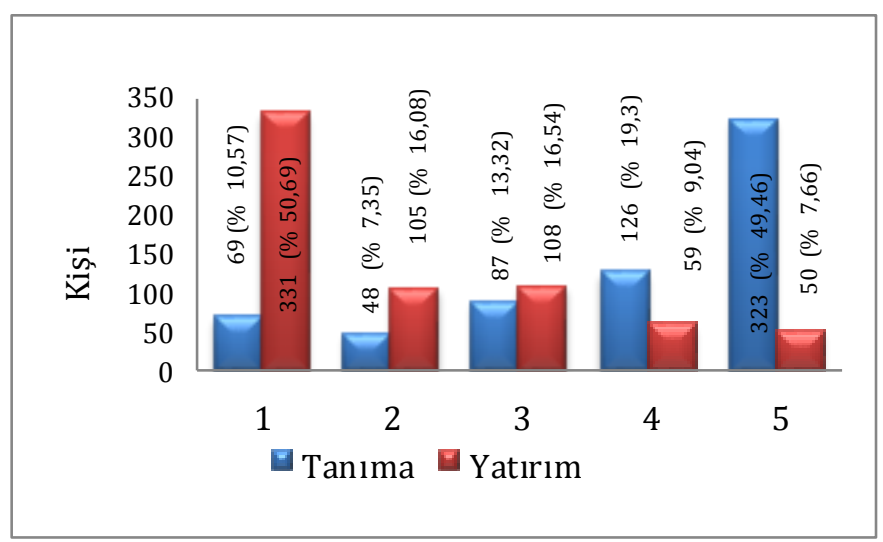

Döviz milli paranın değerini kaybetmesi nedeniyle birikimlerin değerini koruması amacıyla başvurulan bir yatırım aracı olabilmektedir. Grafik 10'da akademisyenlerin "dövizi tanıma" ve "dövize yatırım yapma" durumları görülmektedir. Bu sonuçlara göre dövizi tanırım ya da çok iyi tanırım diyenlerin oranı \% 68,76 olarak çıkmıştır. Akademisyenlerin dövize yatırım durumları da hiç yatırım yapmam ya da yatırım yapmam diyenlerde \% 66,77 iken dövize yatırım yaparım ya da sık sik yatırım yaparım diyenlerin oranı \% 16,7 olarak bulunmuştur. Bilinilirliği yüksek olmakla birlikte dövize yatırım yaptı̆̆ını ifade eden akademisyen oranı daha düşüktür. Milli paranın enflasyonla azalan değerini kısmen karşılasa da istisnai zamanlar haricinde reel anlamda dövizin getiri sağlayan bir yatırım aracı olmadığı düşünülüyor olabilir. 
Grafik 11. Akademisyenlerin Altını Tanıma ve Yatırım Yapma Durumu

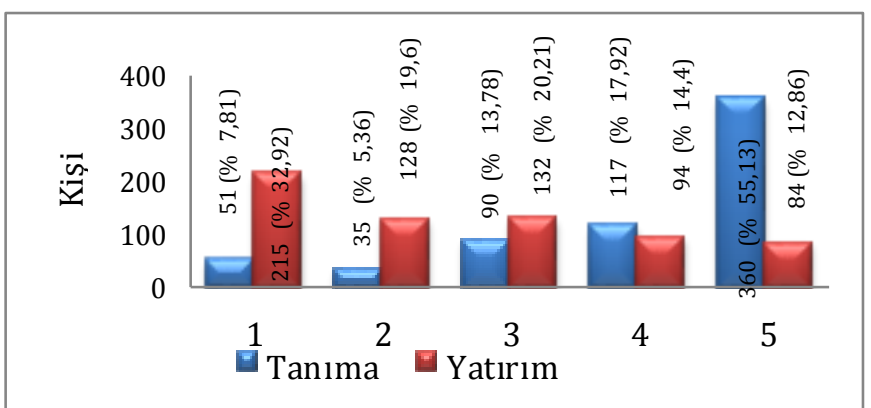

zamanlar hariç yetersiz olduğu düşünülebilir.
Grafik 11'de akademisyenlerin altını bir yatırım aracı olarak "tanıma" ve "altına yatırım yapma" durumları görülmektedir. Altının yatırım aracı olarak yüksek tanınırlık düzeyine göre altına yatırım oranı daha düşük çıkmıştır. Zira altına yatırım yaparım ya da sık sik yatırım yaparım diyenlerin oranı \% 27,26 olarak bulunmuştur. Paranın değerini korumakla birlikte getiri açısından bakıldığında reel anlamda getirinin istisnai

Grafik 12. Akademisyenlerin Altın Kira Sertifikasını Tanıma ve Yatırım Yapma Durumu

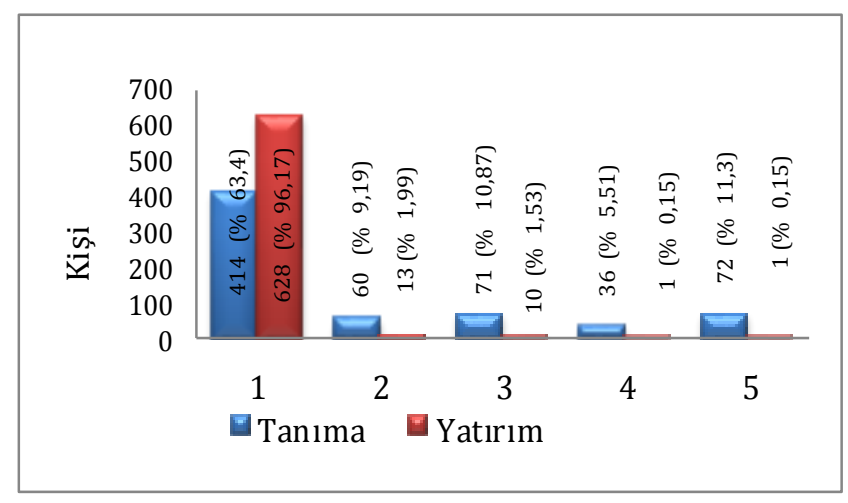

Son zamanlarda ortaya çıkan yeni bir yatırım seçeneği ise altın kira sertifikaları olmuș ve bu alanda paralarını değerlendirmek isteyen yatırımcılar ortaya çıkmıştır. Altın kira sertifikası değeri altına endeksli olan ve ayrıca geliri olan faizsiz bir yatırım aracıdır. Bu aracın akademisyenler tarafından "tanınırlı̆̆ının" ve "yatırım yapma düzeyinin" oldukça düşük düzeylerde olduğu Grafik 12'den anlaşılmaktadır.

Grafik 13. Akademisyenlerin Yatırım Fonunu Tanıma ve Yatırım Yapma Durumu

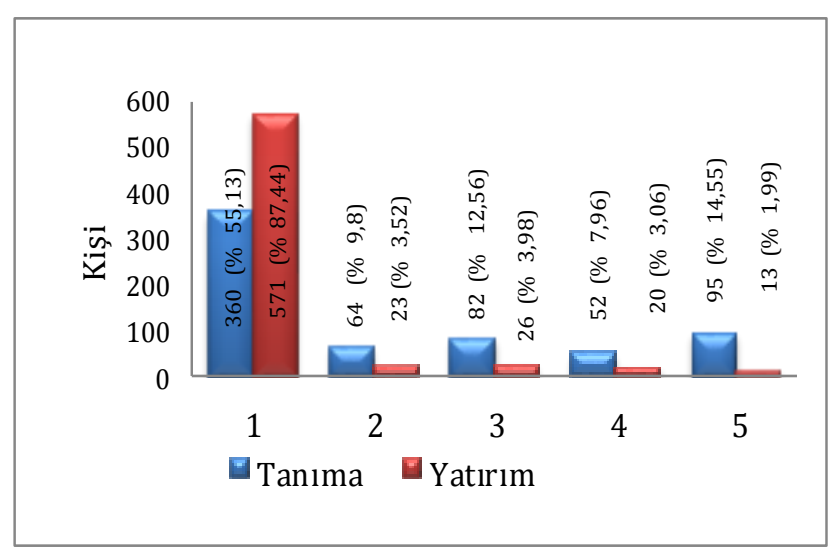

Grafik 13'te akademisyenlerin "yatırım fonlarını tanıma" ve "yatırım fonlarına yatırım yapma durumları" ile ilgili soruya verdikleri cevapların dökümü yer almaktadır. Akademisyenlerin \% 64,93'ü yatırım fonu hakkında bilgisi olmadığını ya da hiç bilgisi olmadığını belirtirken, \% 22,51 oranında akademisyen yatırım fonları hakkında bilgi sahibi olduğunu ya da çok bilgi sahibi olduğunu ortaya koymuştur. Yatırım fonlarına yatırım yapma açısından bakıldı̆̆ında ise \% 90,96 oranında akademisyen yatırım fonlarına hiç yatırım yapmadığını ya da yatırım yapmadığını belirtmiş, \% 5,05 oranında akademisyen yatırım fonlarına yatırım yaptığını açıklamıştır.

Grafik 14. Akademisyenlerin Bireysel Emekliliği Tanıma ve Yatırım Yapma Durumu

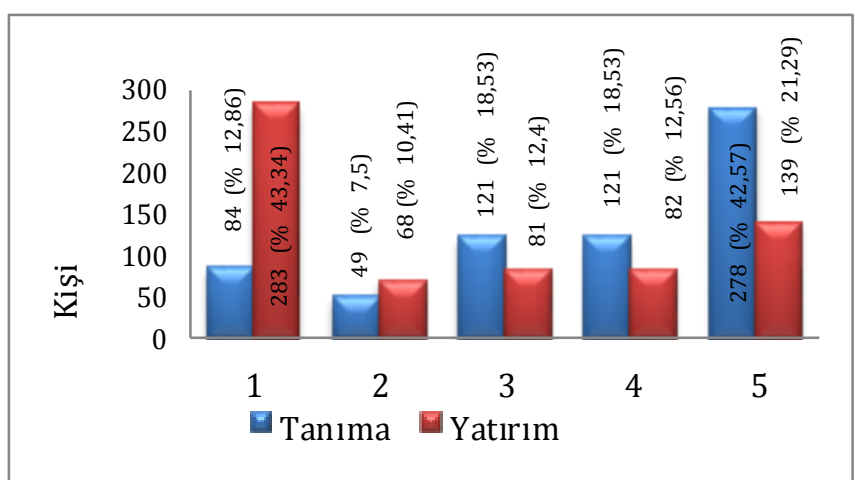

Grafik 14'te akademisyenlerin "bireysel emeklilik sistemini tanıma" durumları ve "bireysel emekliliğe yatırım yapma düzeyleri" görülmektedir. \% 61 oranında akademisyen bireysel emeklilik hakkında bilgi sahibi olduğunu ya da çok iyi bilgiye sahip olduğunu belirtmiştir. Yatırım yapma olarak bakıldığında ise $\quad \% 43.34$ oranında akademisyen bireysel emekliliğe hiç yatırım yapmadığını, $\quad \% 10.41$ 'lik bir oranın ise yatırım yapmadığı, yatırım yapıyorum ve çok 
sık yatırım yapıyorum seçeneğini işaretleyenlerin oranı \% 35'e yakın çıkmıştır. Diğer yatırım araçlarına göre oransal olarak yatırım miktarının yüksek olmasının nedeni Bireysel Emeklilik Sistemine katılımın zorunlu hale getirilmesi olabilir.

Grafik 15. Akademisyenlerin Yatırım Ortaklıklarını Tanıma ve Yatırım Yapma Durumu

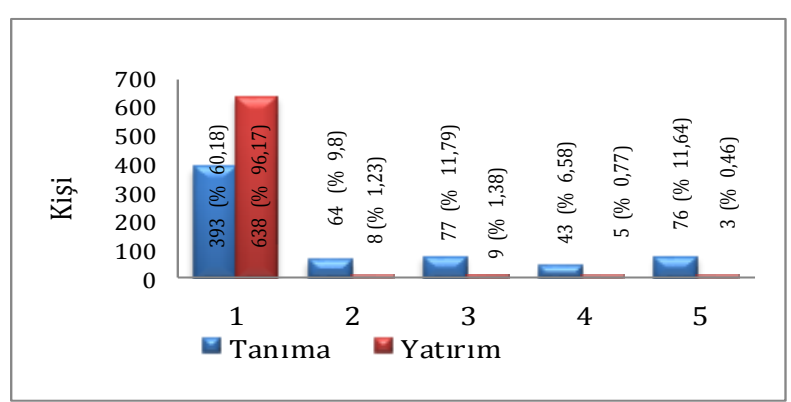

Grafik 15 'te akademisyenlerin yatırım ortaklıkları ile ilgili cevapları görülmektedir. Akademisyenlerin "yatırım ortaklıklarını ne düzeyde tanıdıkları" sorulmuş katılımcıların \% 69.98'i yatırım ortaklıklarını hiç tanımadıklarını ya da tanımadıklarını beyan etmişlerdir. Verilen cevaplara göre yatırım ortaklıkları hakkında bilgi sahibi olduklarını ifade eden akademisyenlerin oranı \% 18,22'dir. Yatırım ortaklıklarına yatırım yapıp yapmadıkları sorusuna ise sadece $\% 1,23$ oranında akademisyen bu araçlara yatırım yaptıklarını belirtmiştir. Bu yatırım aracının akademisyenler tarafından tanınmadığı ifade edilebilir.

Tablo 2: Akademisyenlerin Borsaya (Hisse Senetleri) Yatırım Yapma İle İlgili Davranışları

\begin{tabular}{lcccc}
\hline \hline & \multicolumn{2}{c}{ EVET } & \multicolumn{2}{c}{ HAYIR } \\
\hline \hline & FREKANS & $\begin{array}{c}\text { YÜZDE } \\
\text { (\%) }\end{array}$ & $\begin{array}{c}\text { FREKANS } \\
\text { YÜZDE } \\
\text { (\%) }\end{array}$ \\
\hline \hline Borsaya yatırım yapıyor musunuz? & 82 & 12.56 & 571 & 87.44 \\
\hline \hline Eğer borsaya yatırım yapmıs olsaydınız: & & & & \\
\hline \hline Borsaya bir yıldan uzun vadeli yatırım yapardım. & 72 & 11.03 & 581 & 88.97 \\
\hline \hline Hisse senedini alacağım șirketi kendim analiz ederdim. & 136 & 20.83 & 517 & 79.17 \\
\hline \hline $\begin{array}{l}\text { Alacağım hisse senedini aldığım duyumlara göre } \\
\text { belirlerdim. }\end{array}$ & 71 & 10.87 & 582 & 89.13 \\
\hline \hline Bir yatırım danıșmanı yardımıyla hisse senedi alırdım. & 128 & 19.60 & 525 & 80.40 \\
\hline \hline
\end{tabular}

Tablo 2'de borsa yatırımları konusunda sorulan sorulara yatırımcıların verdikleri cevaplar ele alındığında akademisyenlerin \% 12,56'sının borsaya (hisse senetleri) yatırım yaptığı anlaşılmaktadır. Borsaya yatırım yapmadığını beyan eden akademisyenleri oranı \% 87,44'tür. Eğer borsaya yatırım yapmış olsaydınız aşağıdaki sorulara cevabınız ne olurdu sorusuna karşılık, borsaya bir yıldan uzun vadeli yatırım yapardım diyen akademisyenlerin oranı \% 11,03'tür. Bu soruya "hayır" diyenlerin oranı ise $\% 88,97$ 'dir. Hisse senedi alınan şirketin analizini kendim yapardım diyen akademisyenlerin oranı $\%$ 20,83'tür. Geri kalın \% 79,17 oranında akademisyen analizi kendisinin yapmayacağını muhtemelen uzman desteği alacağını ifade etmiştir. Hangi şirketin hisselerini tercih edeceğimi aldığım duyumlara göre belirlerim diyenlerin oranı \% 10,87, buna "hayır" diyenlerin oranı ise \% 89,13'tür. Bu soruya verilen cevapların oranı akademisyenlerin çoğunlukla duygusal hareket etmek istemediklerini ifade etmektedir. Hisse senedi alınması durumunda bir yatırım danışmanının desteğini alırım diyenlerin oranı \% 19,60, yatırım danışmanı kullanmaya "hayır" cevabı verenlerin oranı ise \% 80,40 olarak bulunmuştur. Yatırım danışmanı kullanma düşüncesi olumlu olmakla birlikte oran düşüktür, büyük çoğunluk yatırım danışmanı kullanma eğiliminde olmadığını belirtmiştir.

Tablo 3'te bireysel yatırım araçlarının akademisyenler tarafından tanınma oranları ve yatırım yapma oranları sıralanmıştır. Bu sonuçlara göre en çok tanınan beş bireysel yatırım aracı altın $(\% 73,05)$, döviz (\% 68,76), gayrimenkul (\% 67,53), otomobil $(\% 64,47)$ ve bireysel emeklilik sistemi ( $\% 61,10)$ olarak bulunmuştur. En az tanınan beş bireysel yatırım aracı ise hazine bonosu ve tahvil $(\% 23,12)$, yatırım fonu $(\% 22,51)$, yatırım ortaklığı $(\% 18,22)$, altın kira sertifikası $(\% 16,54)$ ve forex piyasalar (\% 16,08) olmuştur.

En çok yatırım yapılan beş bireysel yatırım aracı ise yüzde olarak bireysel emeklilik $(\% 33,85)$, gayrimenkul $(\% 28,02)$, altın $(\% 27,26)$, otomobil $(\% 21,28)$ ve döviz $(\% 16,07)$ 'dir. En az yatırım yapılan bireysel yatırım araçları ise bitcoin $(\% 1,99)$, repo $(\% 1,38)$, forex $(\% 1,38)$, yatırım ortaklıkları $(\% 1,23)$ ve altın kira sertifikası $(\% 0,30)^{\prime}$ dır. 
Tablo 3: Bireysel Yatırım Araçlarını Tanıma ve Yatırım Durumu

\begin{tabular}{|c|c|c|c|c|}
\hline & YATIRIM ARAÇLARI & TANIMA (\%) & YATIRIM ARAÇLARI & YATIRIM (\%) \\
\hline 1 & Altın & 73,05 & Bireysel Emeklilik & 33,85 \\
\hline 2 & Döviz & 68,76 & Gayrimenkul & 28,02 \\
\hline 3 & Gayrimenkul & 67,53 & Altın & 27,26 \\
\hline 4 & Otomobil & 64,47 & Otomobil & 21,28 \\
\hline 5 & Bireysel Emeklilik & 61,1 & Döviz & 16,7 \\
\hline \hline 6 & Faizli enstrümanlar & 53,3 & Faizsiz finans Kurumları & 7,81 \\
\hline 7 & Faizsiz finans Kurumları & 39,2 & Faizli enstrümanlar & 7,66 \\
\hline 8 & Hisse senetleri & 32,91 & Yatırım Fonu & 5,05 \\
\hline 9 & Repo & 23,74 & Hisse senetleri & 4,44 \\
\hline \hline 10 & Bitcoin vb. sanal para & 23,28 & Hazine bonosu, tahvil & 2,14 \\
\hline 11 & Hazine bonosu, tahvil & 23,12 & Bitcoin vb. sanal para & 1,99 \\
\hline 12 & Yatırım Fonu & 22,51 & Repo & 1,38 \\
\hline \hline 13 & Yatırım Ortaklığı & 18,22 & Forex piyasalar & 1,38 \\
\hline 14 & Altın Kira Sertifikası & 16,54 & Yatırm Ortaklığı & 1,23 \\
\hline 15 & Forex piyasalar & 16,08 & Altın Kira Sertifikası & 0,3 \\
\hline \hline & Ortalama & $\mathbf{4 0 , 2 5}$ & Ortalama & $\mathbf{1 0 , 6 9}$ \\
\hline \hline
\end{tabular}

\subsection{1.İstatistiksel Analiz}

$\mathrm{Bu}$ bölümde demografik değişkenlerle yatırım araçları arasında farklılık olup olmadı̆̆ istatistiksel olarak analiz edilmektedir. Bunun için araştırmadan elde edilen verilerin öncelikle güvenilirlik düzeyi hesaplanmıș ve verilerin güvenilirliğini ifade eden Cronbach's Alpha katsayısı $(0,913)$ olarak hesaplanmış olup bu değer yüksek düzeyde ölçek güvenilirliğini ifade etmektedir. Yüksek güvenilirlikte ölçek: $0,80<\& \leq 1$ (Sarıgül, 2015: 206). Kolmogorov Smirnov ve Shapiro Wilk Testleriyle normallik testi yapılmış ve yapılan normallik testi sonuçlarına göre verilerin normal dağılmadığı görülmüş dolayısıyla non-parametrik testlerden Mann Whithney U-Testi ile Kruskal Wallis Testi uygulanmıştır. Elde edilen sonuçlar tablolar halinde özetlenmiştir.

Tablo 4: Cinsiyetle yatırım araçları arasında farklılık analizi (Mann Whithney U)

\begin{tabular}{|c|c|c|c|c|c|}
\hline Yatırım Araçları & Cinsiyet & $\mathbf{N}$ & $\begin{array}{c}\text { Sira } \\
\text { Ortalaması } \\
\end{array}$ & $\mathbf{U}$ & $\mathbf{P}$ \\
\hline \multirow{3}{*}{$\begin{array}{l}\text { Hisse senetleri } \\
\text { hakkında bilgi sahibi } \\
\text { olma durumu }\end{array}$} & Erkek & 455 & 354,62 & \multirow{3}{*}{32476,500} & \multirow{3}{*}{,000 } \\
\hline & Kadın & 198 & 263,52 & & \\
\hline & Toplam & 653 & & & \\
\hline \multirow{3}{*}{$\begin{array}{c}\text { Hisse senetlerine } \\
\text { yatırım yapma } \\
\text { durumu } \\
\end{array}$} & Erkek & 455 & 337,68 & \multirow{3}{*}{40184,500} & \multirow{3}{*}{,000 } \\
\hline & Kadın & 198 & 302,45 & & \\
\hline & Toplam & 653 & & & \\
\hline \multirow{3}{*}{$\begin{array}{l}\text { Faiz seçeneğini } \\
\text { tanıma durumu }\end{array}$} & Erkek & 455 & 345,31 & \multirow{3}{*}{36716,000} & \multirow{3}{*}{,000 } \\
\hline & Kadın & 198 & 284,93 & & \\
\hline & Toplam & 653 & & & \\
\hline \multirow{3}{*}{$\begin{array}{c}\text { Faize yatırım yapma } \\
\text { durumu }\end{array}$} & Erkek & 455 & 320,50 & \multirow{3}{*}{42088,500} & \multirow{3}{*}{,043 } \\
\hline & Kadın & 198 & 341,93 & & \\
\hline & Toplam & 653 & & & \\
\hline \multirow{3}{*}{$\begin{array}{c}\text { Gayrimenkul } \\
\text { yatırımlarını tanıma } \\
\text { durumu }\end{array}$} & Erkek & 455 & 335,09 & \multirow{3}{*}{41363,000} & \multirow{3}{*}{,077 } \\
\hline & Kadın & 198 & 308,40 & & \\
\hline & Toplam & 653 & & & \\
\hline \multirow{3}{*}{$\begin{array}{l}\text { Gayrimenkule yatırım } \\
\text { yapma durumu }\end{array}$} & Erkek & 455 & 334,23 & \multirow{3}{*}{41753,500} & \multirow{3}{*}{,123 } \\
\hline & Kadın & 198 & 310,38 & & \\
\hline & Toplam & 653 & & & \\
\hline
\end{tabular}

\section{R\&S}

Research Studies Anatolia Journal

Volume: 2, Issue:4, January 2019 


\begin{tabular}{cccccc}
\hline & Erkek & 455 & 332,78 & & \\
Altını tanıma durumu & Kadın & 198 & 313,71 & 42413,000 &, 190 \\
& Toplam & 653 & & & \\
\hline \multirow{2}{*}{$\begin{array}{c}\text { Altını yatırım yapma } \\
\text { durumu }\end{array}$} & Erkek & 455 & 322,25 & & \\
& Kadın & 198 & 337,92 & 42838,000 &, 35
\end{tabular}

Anketimize katılan akademisyen grubunun yatırım araçlarını "tanıma" ve "yatırım yapma" hakkında cinsiyete göre farklılık olup olmadığı Mann Whitney U Testi ile analiz edilmiş ve sonuçlar Tablo 4'te gösterilmiştir. Cinsiyete göre hisse senedi ve faizi tanıma ve yatırım ile ilgili olarak istatistiksel açıdan anlamlı farklılık gözlemlenmiştir. Hisse senetlerini tanıma ve yatırım yapma ve faizi tanıma konusunda erkeklerin ortalaması daha yüksek olduğu halde, faize yatırım yapma konusunda kadınlar daha yüksek bir ortalamaya sahiptir. Bu sonuçlar erkeklerin risk almaya daha fazla eğilimli olduklarını ancak kadın akademisyenlerin risksiz yatırım aracı olan faizi tercih ettiklerini göstermektedir.

Tablo 5: Calıșma alanıyla yatırım araçları arasında farklılık analizi (Kruskal Wallis)

\begin{tabular}{|c|c|c|c|c|c|}
\hline Yatırım Araçları & $\begin{array}{c}\text { Anketi Cevaplandıranın } \\
\text { Bilim Alanı } \\
\end{array}$ & $\mathbf{N}$ & $\begin{array}{c}\text { Sira } \\
\text { Ortalaması } \\
\end{array}$ & $\mathrm{X}^{2}$ & $\mathbf{P}$ \\
\hline \multirow{5}{*}{$\begin{array}{l}\text { Hisse senetleri hakkında } \\
\text { bilgi sahibi olma durumu }\end{array}$} & Sosyal Bilimler & 374 & 373,39 & \multirow{5}{*}{62,792} & \multirow{5}{*}{,000 } \\
\hline & Fen Bilimleri & 107 & 271,27 & & \\
\hline & Sağlık Bilimleri & 87 & 232,07 & & \\
\hline & Mühendislik Bilimleri & 64 & 289,60 & & \\
\hline & Diğer & 21 & 291,98 & & \\
\hline \multirow{5}{*}{$\begin{array}{c}\text { Hisse senetlerine yatırım } \\
\text { yapma durumu }\end{array}$} & Sosyal Bilimler & 374 & 342,52 & \multirow{5}{*}{18,436} & \multirow{5}{*}{,001 } \\
\hline & Fen Bilimleri & 107 & 304,18 & & \\
\hline & Sağlık Bilimleri & 87 & 298,40 & & \\
\hline & Mühendislik Bilimleri & 64 & 305,33 & & \\
\hline & Diğer & 21 & 351,43 & & \\
\hline \multirow{5}{*}{$\begin{array}{l}\text { Faiz seçeneğini tanıma } \\
\text { durumu }\end{array}$} & Sosyal Bilimler & 374 & 362,55 & \multirow{5}{*}{36,954} & \multirow{5}{*}{,000 } \\
\hline & Fen Bilimleri & 107 & 285,54 & & \\
\hline & Sağlık Bilimleri & 87 & 255,99 & & \\
\hline & Mühendislik Bilimleri & 64 & 286,32 & & \\
\hline & Diğer & 21 & 323,21 & & \\
\hline \multirow{5}{*}{$\begin{array}{c}\text { Faize yatırım yapma } \\
\text { durumu }\end{array}$} & Sosyal Bilimler & 374 & 325,91 & \multirow{5}{*}{7,255} & \multirow{5}{*}{,123 } \\
\hline & Fen Bilimleri & 107 & 353,53 & & \\
\hline & Sağlık Bilimleri & 87 & 315,85 & & \\
\hline & Mühendislik Bilimleri & 64 & 311,15 & & \\
\hline & Diğer & 21 & 305,79 & & \\
\hline \multirow{5}{*}{$\begin{array}{l}\text { Gayrimenkul yatırımlarını } \\
\text { tanıma durumu }\end{array}$} & Sosyal Bilimler & 374 & 360,08 & \multirow{5}{*}{38,053} & \multirow{5}{*}{,000 } \\
\hline & Fen Bilimleri & 107 & 291,95 & & \\
\hline & Sağlık Bilimleri & 87 & 241,32 & & \\
\hline & Mühendislik Bilimleri & 64 & 311,85 & & \\
\hline & Diğer & 21 & 317,52 & & \\
\hline \multirow{5}{*}{$\begin{array}{l}\text { Gayrimenkule yatırım } \\
\text { yapma durumu }\end{array}$} & Sosyal Bilimler & 374 & 342,97 & \multirow{5}{*}{7,192} & \multirow{5}{*}{,126 } \\
\hline & Fen Bilimleri & 107 & 309,57 & & \\
\hline & Sağlık Bilimleri & 87 & 297,30 & & \\
\hline & Mühendislik Bilimleri & 64 & 313,88 & & \\
\hline & Diğer & 21 & 294,50 & & \\
\hline \multirow{5}{*}{ Altını tanıma durumu } & Sosyal Bilimler & 374 & 356,75 & \multirow{5}{*}{31,643} & \multirow{5}{*}{,000 } \\
\hline & Fen Bilimleri & 107 & 292,63 & & \\
\hline & Sağlık Bilimleri & 87 & 256,41 & & \\
\hline & Mühendislik Bilimleri & 64 & 319,13 & & \\
\hline & Diğer & 21 & 288,67 & & \\
\hline \multirow{5}{*}{$\begin{array}{c}\text { Altına yatırım yapma } \\
\text { durumu }\end{array}$} & Sosyal Bilimler & 374 & 336,62 & \multirow{5}{*}{5,318} & \multirow{5}{*}{,256 } \\
\hline & Fen Bilimleri & 107 & 318,88 & & \\
\hline & Sağlık Bilimleri & 87 & 311,60 & & \\
\hline & Mühendislik Bilimleri & 64 & 329,63 & & \\
\hline & Diğer & 21 & 252,74 & & \\
\hline
\end{tabular}


Anket uygulanan akademisyen grubunun "yatırım araçlarını tanıma" ve "yatırım yapma" hakkında çalışma alanına göre farklılık olup olmadığı Kruskal Wallis Testi ile analiz edilmiş ve sonuçlar Tablo 5 'te gösterilmiştir. Sonuçlar akademisyenlerin bilim alanına göre hisse senedini tanıma ve yatırım, faizi tanıma, gayrimenkulü tanıma ve altını tanıma konusunda istatistiksel açıdan anlamlı farklılık gözlemlenmiştir. Hisse senedini tanıma ve yatırım ile faizi tanıma konusunda sosyal bilimcilerin ortalaması yüksek çıkmıştır. Diğer alanlarda faaliyet gösteren akademisyenler birbirine yakın ortalamalara sahiptir. Gayrimenkulü ve altını tanıma konusunda en yüksek ortalamaya sahip olan kesim sosyal bilimciler iken alanı mühendislik olanlar ikinci en yüksek ortalamaya sahiptir.

Tablo 6: Aylık Gelir İle Yatırım Araçları Arasında Farklılık Analizi (Kruskal Wallis)

\begin{tabular}{|c|c|c|c|c|c|}
\hline Yatırım Araçları & $\begin{array}{c}\text { Anketi } \\
\text { cevaplandıranın } \\
\text { aylık geliri }\end{array}$ & $\mathbf{N}$ & $\begin{array}{c}\text { Sira } \\
\text { Ortalaması }\end{array}$ & Ki-Kare & $\mathbf{P}$ \\
\hline \multirow{5}{*}{$\begin{array}{l}\text { Hisse senetleri hakkında } \\
\text { bilgi sahibi olma durumu }\end{array}$} & $3.000-4.500 \mathrm{TL}$ & 15 & 288,60 & \multirow{5}{*}{3,674} & \multirow{5}{*}{,452 } \\
\hline & $4.500-6.000 \mathrm{TL}$ & 261 & 325,72 & & \\
\hline & $6.000-7.500 \mathrm{TL}$ & 141 & 309,34 & & \\
\hline & $7.500-9.000 \mathrm{TL}$ & 98 & 346,04 & & \\
\hline & Daha Fazla & 138 & 338,13 & & \\
\hline \multirow{5}{*}{$\begin{array}{l}\text { Hisse senetlerine yatırım } \\
\text { yapma durumu }\end{array}$} & $3.000-4.500 \mathrm{TL}$ & 15 & 296,20 & \multirow{5}{*}{3,942} & \multirow{5}{*}{,414 } \\
\hline & $4.500-6.000 \mathrm{TL}$ & 261 & 318,38 & & \\
\hline & $6.000-7.500 \mathrm{TL}$ & 141 & 332,01 & & \\
\hline & 7.500-9.000 TL & 98 & 332,73 & & \\
\hline & Daha Fazla & 138 & 337,46 & & \\
\hline \multirow{5}{*}{$\begin{array}{l}\text { Faiz seçeneğini tanıma } \\
\text { durumu }\end{array}$} & $3.000-4.500 \mathrm{TL}$ & 15 & 279,33 & \multirow{5}{*}{3,735} & \multirow{5}{*}{,443 } \\
\hline & $4.500-6.000 \mathrm{TL}$ & 261 & 318,78 & & \\
\hline & $6.000-7.500 \mathrm{TL}$ & 141 & 320,08 & & \\
\hline & $7.500-9.000 \mathrm{TL}$ & 98 & 341,24 & & \\
\hline & Daha Fazla & 138 & 344,68 & & \\
\hline \multirow{5}{*}{$\begin{array}{c}\text { Faize yatırım yapma } \\
\text { durumu }\end{array}$} & $3.000-4.500 \mathrm{TL}$ & 15 & 337,43 & \multirow{5}{*}{9,296} & \multirow{5}{*}{,054 } \\
\hline & $4.500-6.000 \mathrm{TL}$ & 261 & 314,19 & & \\
\hline & $6.000-7.500 \mathrm{TL}$ & 141 & 319,42 & & \\
\hline & $7.500-9.000 \mathrm{TL}$ & 98 & 335,81 & & \\
\hline & Daha Fazla & 138 & 351,59 & & \\
\hline \multirow{5}{*}{$\begin{array}{c}\text { Gayrimenkul yatırımlarını } \\
\text { tanıma durumu }\end{array}$} & $3.000-4.500 \mathrm{TL}$ & 15 & 291,33 & \multirow{5}{*}{1,808} & \multirow{5}{*}{,771 } \\
\hline & $4.500-6.000 \mathrm{TL}$ & 261 & 325,96 & & \\
\hline & $6.000-7.500 \mathrm{TL}$ & 141 & 320,25 & & \\
\hline & 7.500-9.000 TL & 98 & 344,80 & & \\
\hline & Daha Fazla & 138 & 327,09 & & \\
\hline \multirow{5}{*}{$\begin{array}{l}\text { Gayrimenkule yatırım } \\
\text { yapma durumu }\end{array}$} & $3.000-4.500 \mathrm{TL}$ & 15 & 268,97 & \multirow{5}{*}{44,669} & \multirow{5}{*}{, 000} \\
\hline & $4.500-6.000 \mathrm{TL}$ & 261 & 279,75 & & \\
\hline & $6.000-7.500 \mathrm{TL}$ & 141 & 320,89 & & \\
\hline & $7.500-9.000 \mathrm{TL}$ & 98 & 386,02 & & \\
\hline & Daha Fazla & 138 & 387,01 & & \\
\hline \multirow{5}{*}{ Altını tanıma durumu } & $3.000-4.500 \mathrm{TL}$ & 15 & 307,07 & \multirow{5}{*}{1,297} & \multirow{5}{*}{,862 } \\
\hline & $4.500-6.000 \mathrm{TL}$ & 261 & 334,04 & & \\
\hline & $6.000-7.500 \mathrm{TL}$ & 141 & 324,23 & & \\
\hline & 7.500-9.000 TL & 98 & 330,72 & & \\
\hline & Daha Fazla & 138 & 316,03 & & \\
\hline \multirow{5}{*}{$\begin{array}{c}\text { Altına yatırım yapma } \\
\text { durumu }\end{array}$} & $3.000-4.500 \mathrm{TL}$ & 15 & 312,67 & \multirow{5}{*}{643} & \multirow{5}{*}{,958 } \\
\hline & $4.500-6.000 \mathrm{TL}$ & 261 & 322,12 & & \\
\hline & $6.000-7.500 \mathrm{TL}$ & 141 & 327,35 & & \\
\hline & $7.500-9.000 \mathrm{TL}$ & 98 & 337,67 & & \\
\hline & Daha Fazla & 138 & 329,84 & & \\
\hline
\end{tabular}

Örneğimizi akademisyen grubunun yatırım araçlarını tanıma ve yatırım yapma hakkında aylık gelir düzeyine göre istatistiksel açıdan anlamlı farklılık olup olmadığı Kruskal Wallis Testi ile analiz edilmiş ve sonuçlar Tablo 6'da gösterilmiştir. Elde edilen sonuçlar akademisyenlerin aylık gelirlerine göre gayrimenkule yatırım yapma konusunda istatistiksel açıdan anlamlı farklılık olduğunu göstermektedir. 
Ortalamalar incelendiğinde gelir durumu yükseldikçe gayrimenkule daha fazla yatırım yapıldığı görülebilir. Ortalamalar gelir düzeyine paralel bir artış göstermektedir.

Tablo 7: Aylık Tasarruf Miktarı İle Yatırım Araçları Arasında Farklılık Analizi (Kruskal Wallis)

\begin{tabular}{|c|c|c|c|c|c|}
\hline & $\begin{array}{c}\text { Anketi } \\
\text { Cevaplandıranın } \\
\text { Aylık Tasarrufu }\end{array}$ & $\mathbf{N}$ & $\begin{array}{c}\text { Sira } \\
\text { Ortalaması }\end{array}$ & $\mathbf{X}^{2}$ & $\mathbf{P}$ \\
\hline \multirow{4}{*}{$\begin{array}{l}\text { Hisse senetleri hakkında bilgi } \\
\text { sahibi olma durumu }\end{array}$} & $0-500 \mathrm{TL}$ & 173 & 296,99 & \multirow{4}{*}{6,720} & \multirow{4}{*}{,081 } \\
\hline & $500-1.500 \mathrm{TL}$ & 180 & 342,23 & & \\
\hline & $1.500-3.000 \mathrm{TL}$ & 182 & 336,05 & & \\
\hline & Daha Fazla & 118 & 333,81 & & \\
\hline \multirow{4}{*}{$\begin{array}{l}\text { Hisse senetlerine yatırım } \\
\text { yapma durumu }\end{array}$} & $0-500 \mathrm{TL}$ & 173 & 308,48 & \multirow{4}{*}{8,538} & \multirow{4}{*}{,036 } \\
\hline & $500-1.500 \mathrm{TL}$ & 180 & 322,12 & & \\
\hline & $1.500-3.000 \mathrm{TL}$ & 182 & 339,15 & & \\
\hline & Daha Fazla & 118 & 342,87 & & \\
\hline \multirow{4}{*}{$\begin{array}{l}\text { Faiz seçeneğini tanıma } \\
\text { durumu }\end{array}$} & $0-500 \mathrm{TL}$ & 173 & 295,46 & \multirow{4}{*}{8,060} & \multirow{4}{*}{045} \\
\hline & $500-1.500 \mathrm{TL}$ & 180 & 348,03 & & \\
\hline & $1.500-3.000 \mathrm{TL}$ & 182 & 331,05 & & \\
\hline & Daha Fazla & 118 & 334,93 & & \\
\hline \multirow{4}{*}{ Faize yatırım yapma durumu } & $0-500 \mathrm{TL}$ & 173 & 305,84 & \multirow{4}{*}{7,377} & \multirow{4}{*}{,061 } \\
\hline & $500-1.500 \mathrm{TL}$ & 180 & 339,64 & & \\
\hline & $1.500-3.000 \mathrm{TL}$ & 182 & 329,91 & & \\
\hline & Daha Fazla & 118 & 334,26 & & \\
\hline \multirow{4}{*}{$\begin{array}{l}\text { Gayrimenkul yatırımlarını } \\
\text { tanıma durumu }\end{array}$} & $0-500 \mathrm{TL}$ & 173 & 310,36 & \multirow{4}{*}{3,674} & \multirow{4}{*}{ 299 } \\
\hline & $500-1.500 \mathrm{TL}$ & 180 & 344,16 & & \\
\hline & $1.500-3.000 \mathrm{TL}$ & 182 & 320,71 & & \\
\hline & Daha Fazla & 118 & 334,92 & & \\
\hline \multirow{4}{*}{$\begin{array}{c}\text { Gayrimenkule yatırım yapma } \\
\text { durumu }\end{array}$} & $0-500 \mathrm{TL}$ & 173 & 266,21 & \multirow{4}{*}{64,834} & \multirow{4}{*}{,000 } \\
\hline & $500-1.500 \mathrm{TL}$ & 180 & 291,15 & & \\
\hline & $1.500-3.000 \mathrm{TL}$ & 182 & 357,57 & & \\
\hline & Daha Fazla & 118 & 423,67 & & \\
\hline \multirow{4}{*}{ Altını tanıma durumu } & $0-500 \mathrm{TL}$ & 173 & 310,27 & \multirow{4}{*}{4,560} & \multirow{4}{*}{ 207 } \\
\hline & $500-1.500 \mathrm{TL}$ & 180 & 334,82 & & \\
\hline & $1.500-3.000 \mathrm{TL}$ & 182 & 343,96 & & \\
\hline & Daha Fazla & 118 & 313,45 & & \\
\hline \multirow{4}{*}{ Altına yatırım yapma durumu } & $0-500 \mathrm{TL}$ & 173 & 261,07 & \multirow{4}{*}{34,867} & \multirow{4}{*}{,000 } \\
\hline & $500-1.500 \mathrm{TL}$ & 180 & 328,18 & & \\
\hline & $1.500-3.000 \mathrm{TL}$ & 182 & 365,54 & & \\
\hline & Daha Fazla & 118 & 362,42 & & \\
\hline
\end{tabular}

Örneklemimizi oluşturan akademisyen grubunun yatırım araçlarını tanıma ve yatırım yapma hakkında aylık tasarruf düzeyine göre istatistiksel açıdan anlamlı farklılık olup olmadığı Kruskal Wallis Testi ile analiz edilmiş ve sonuçlar Tablo 7'de gösterilmiştir. Elde edilen sonuçlar akademisyenlerin aylık tasarruf düzeylerine göre hisse senetlerine yatırım, faizi tanıma, gayrimenkule ve altına yatırım yapma konusunda istatistiksel açıdan anlamlı farklılık olduğunu göstermektedir. Sonuçlara göre tasarruf düzeyi yükseldikçe hisse senetlerine, gayrimenkule ve altına yatırım yapma ortalaması da artış göstermektedir. Aynı şey faizi tanıma açısından da söylenebilir, ancak faize yatırım yapma konusunda tasarruf açısından farklılık söz konusu değildir.

\section{SONUÇ VE ÖNERÍLER}

Araştırmaya katkı sağlayan 653 akademisyenin anket sorularına verdiği cevaplar değerlendirilmiş ve sonuçlar frekans ve yüzde olarak tablolar halinde sunulmuştur. Ankete verilen cevapların değerlendirilmesinden çıkartılabilecek belli başlı araştırma sonuçları aşağıda sıralanmaktadır.

Akademisyenlerin ifadelerine göre en çok tanıdıkları yatırım araçları yüzdelik sırasına göre altın (\% 73,05), döviz (\% 68,76), gayrimenkul (\% 67,53), otomobil (\% 64,47), Bireysel Emeklilik Sistemi $(\%$ $61,1)$ ve faizli yatırım araçları (\% 53,3)'dır. Ankette yer verilen diğer yatırım araçlarının (hisse senedi, repo, sanal para, hazine bonosu, yatırım fonu, yatırım ortaklığı, altın kira sertifikası, forex) akademisyenler tarafından tanınırlığı \% 50'nin altında çıkmıştır.

\section{R\&S}

Research Studies Anatolia Journal

Volume: 2, Issue:4, January 2019 
Akademisyenler tarafından en çok yatırım yapıldığı ifade edilen yatırım araçları Bireysel Emeklilik Sistemi $(\% 33,85)$, gayrimenkul $(\% 28,02)$, altın $(\% 27,26)$, otomobil $(\% 21,28)$ ve döviz $(\% 16,7)$ 'dir. Diğer yatırım araçlarına yapılan yatırım tutarı \% 0,2 ile \% 7,81 oranları arasında ve düşük düzeydir. Bireysel Emeklilik Sistemine yapılan yatırım oranının yüksek çıkması çalışanların sisteme yasal olarak dahil edilmesinden kaynaklanmış olabilir. Bu sonuçlar Doğan vd. (2016)'nin yaptığı araștırma sonuçlarına kısmi benzerlik göstermektedir. Söz konusu araştırmada banka personelinin yatırım eğilimleri araştırılmış ve en çok yatırım yapılan araçlar sırasıyla banka mevduatı, altın, hisse senedi ve diğer şeklinde sıralanmıştır.

Frekans analizi sonuçlarına göre "Tanınma Oranları" ile "Yatırım Yapma Oranları" karşılaştırıldığında arada önemli fark vardır. Tanınırlık oranı ortalaması \% 40,25 iken yatırım yapma ortalaması \% 10,70 olarak hesaplanmıştır. Bu sonuç genel olarak akademisyenlerin yatırım araçları hakkında bir takım çekinceleri olduğunu göstermektedir.

İstatistiksel analiz sonuçlarına göre akademisyenlerin yatırım araçlarını tanıma ve yatırım yapma durumları "cinsiyet", "yaş", "gelir" ve "tasarruf düzeyi”ne göre farklılık göstermektedir. Erkek akademisyenlerin ağırlıklı olarak riskli yatırımlara daha fazla eğilim gösterdiği, buna karşın kadın akademisyenlerin ağırlıklı olarak riski düşük yatırımlara ilgi duyduğu anlaşılmaktadır. Ayrıca gelir ve tasarruf düzeyinin artmasına paralel olarak yatırım araçlarından hisse senetlerine, gayrimenkule ve altına yatırımın arttığı verilen cevapların sıra istatistiklerinden anlaşılmaktadır. Benzer bir araştırma olan Ece (2017)'nin araştırma sonuçlarına göre ise yatırım tercihleri cinsiyet, yaş ve medeni duruma göre değiş̧mezken, eğitim durumu ve yatırım bilgisi yatırım tercihlerinde önemli olmaktadır.

Yatırım araçlarını tanıma oranı açısından bakıldığında akademisyenlerin finansal okuryazarlık durumları orta düzey olarak kabul edilebilir. Yatırım araçlarını tanıma açısından finansal okuryazarlık durumları orta düzey olan akademisyenlerin yatırım araçlarına yatırım yapmaktan önemli ölçüde kaçındığı ortaya çıkmaktadır. Yatırım araçlarını tanıdığı halde yatırım yapmaktan kaçınmalarının nedenleri ne olabilir? Yatırım araçlarına yapılan yatırım oranının oldukça düşük olmasının bazı nedenleri şu şekilde tahmin edilmektedir: Örneğin; hisse senetlerine yatırımın oldukça düşük düzeylerde olmasının nedeni bu araçların riskli yatırım aracı olması ve piyasalarda yeterli ve sürekli istikrarın olmayışı olabilir. Diğer taraftan faiz getiren yatırım araçlarına yatırımın düşük olması muhtemelen akademisyenlerin faiz karşısındaki dini gerekçeli tutumları, reel faiz getirisinin yetersizliği gibi faktörlerle ilişkilendirilebilir. Yatırımların düşük düzeyde olmasının altında yatan önemli bir sebep de toplumdaki tüketim eğiliminin yüksek olması olabilir. "Gayrimenkul", "konut", "otomobil", "altın" gibi araçlara fazla yatırım yapma nedenleri ise bu araçların hem kullanılması hem de değerini koruması hatta birikimlerin değer kazanması olabilir. Yine de gerçek nedenlerin daha detaylı ve gerçekçi bir şekilde ortaya çıkarılabilmesi için konunun başka bir araştırmaya tabi tutulması uygun olabilir.

Araştırmadan çıkarılabilecek genel bir sonuç, akademisyenlerin tasarruf oranı (\% 25, anket verilerinden hesaplanmıştır) ülkemizin genel tasarruf oranının (2000-2010 yılı ortalaması \% 16) (Özlale ve Karakurt, 2012: 5) üzerinde olmakla birlikte tasarrufların finansal sisteme girerek gerçek anlamda ekonomik yatırımlara finansman sağlaması oldukça düşük düzeydedir. Bunu hisse senedi yatırımlarından anlayabiliyoruz. Çünkü tasarrufların önemli bir kısmı "gayrimenkul", "otomobil" gibi üretken olmayan ve birikimlerin sadece el değiştirdiği yatırımlara gitmektedir. Tasarruf ve yatırım bilincinin artırılmasıyla tasarrufların özellikle hisse senetlerine aktarılarak finansal sisteme dolayısıyla ekonomiye katkı sağlama düzeyi artırılabilir.

Yatırımdan kaçınmanın nedenleri ortaya çıkarılabilirse bu nedenlerin ortadan kaldırılarak ya da şartların iyileştirilmesiyle başta akademisyenlerin sonra da toplumun diğer kesimlerinin "tasarrufyatırım" düzeyleri yükseltilerek ekonomiye daha fazla katkı yapmaları sağlanabilir.

Alınan sonuçlar ve akademisyenlerin sağladı̆̆ı geri dönüşler yatırım danışmanlığına ve finansal okuryazarlık eğitimine ihtiyaç olduğunu ortaya koymaktadır. Bu konularda eğitici seminerler ve danışmanlık hizmetleri verilmesi akademisyenlerin tasarruflarının daha yüksek oranda ekonomik yatırımlara dönüşmesini sağlayabilir. 


\section{KAYNAKÇA}

Akbulut, R. ve Kaderli, Y. (2009). Şanlıurfa İl Merkezindeki Borsa Yatırımcllarının Hisse Senetlerine Yatırım Yapma Sürecini Etkileyen Faktörlerin Analizi, Muhasebe ve Finansman Dergisi, 43. 212-226.

Aksoy, A. ve Cihan, T. (2007). Sermaye Piyasası Yatırım Araçları ve Analizi, 3. Baskı, Gazi Kitabevi, Ankara.

Anbar, A. ve Alper, D. (2014). Yatırım Projeleri Analizi, Ekin Basım Yayın Dağıtım, Bursa.

Atkinson, A. ve F. Messy (2013). Promoting Financial Inclusion Throuh Financial Education: OECD/INFE Evidence, Policies and Practice: OECD Working Papers on Finance, Insurance and Private Pensions, No: 34. OECD:

Bayram, S. S. (2014). Finansal Okuryazarlık ve Para Yönetimi Davranışları. Anadolu Üniversitesi Öğrencileri Üzerinde Bir Uygulama, Business \& Management Studies: An International Journal, Vol.: 2, Issue: 2, 105-135.

Bernheim, D.B., Daniel, M.G. ve Dean, M.M. (1997), Education and Saving: The Long-Term Effects of High School Financial Curriculum Mandates. NBER (National Bureau of Economic Research), Working Paper 6085.

Danışman, E.; Durmuş, S. Ve Umut Tolga, G. (2016). Finansal Okuryazarlık Durumunun Belirlenmesi: Üniversite Öğrencileri Üzerinde Bir Araştırma, Kara Harp Okulu Bilim Dergisi, Aralık, Cilt: 26, Sayı: 2, 1-37.

Doğan, M., Feyyaz, Y. ve Yusuf, T. (2016). Yatırım Tercihlerinin Demografik Özelliklere Bağlı Olarak Değişmesi: Türkiye'deki Banka Çalışanları Üzerinde Bir Uygulama, Journal of Accounting, Finance and Auditing Studies. 2/3. 185-199.

Ece, S. (2017). Bireysel Yatırımcıların Yatırım Davranışlarına Yönelik Bir Araştırma, Uluslararası Sosyal Araştırmalar Dergisi, Cilt: 10, Sayı: 53. 494-501.

Gökmen, H. (2012). Finansal Okuryazarlık, Hiperlink Yayınları, İstanbul, 1. Baskı.

Gutnu, M. M. ve Mehmet, C. (2015), Finansal Okuryazarlık: Osmaniye Korkutata Üniversitesi Personeli Üzerinde Bir Araştırma, Akademik Sosyal Araştırmalar Dergisi, Yıl: 3, Sayı: 10, Mart 2015, 415424.

Hayta, A. B. (2012). Ailelerin Tasarruf ve Yatırım Eğilimlerinin İncelenmesi, Kastamonu Eğitim Dergisi, 16 (2), ss. 345-358.

Hilgerth, M. A., Hogarth, J. M. and Sondra G.B. (2003). Household Financial Management: The Connection Between Knowledge and Behavior, Federal Reserve Bulletin, 89 (7), 309-322.

https://www.aa.com.tr/tr/egitim/yuksekogretim-istatistikleri-aciklandi/ 1133100,

E.T. 30.11.2018.

Küden, M. (2004). Davranışsal Finans Açısından Bireylerin Yatırım Tercihlerinin Değerlendirilmesi (Yayımlanmış Yüksek Lisans Tezi), Gediz Üniversitesi, Sosyal Bilimler Enstitüsü, İzmir.

Özlale, Ü. ve Karakurt, A. (2012). “Türkiye’de Tasarruf Açığının Nedenleri ve Kapatılması İçin Politika Önerileri", Bankacllar Dergisi, 23(83), 1-33.

Pirgaip, B. (2016). Türkiye'de Altın ve Altına Dayalı Yatırım Araçlarının Karşılaştırmalı Performans Analizi, Finans, Politik \& Ekonomik Yorumlar, Cilt: 53, Sayı: 619, 9-23.

Rana, H. M., Chan, J. Ve Baig, A.A. (2014). Information Searchers As a Mediator Between Income and Risky Decision-Making Behavior And Influence of Education On Risky-Decision-Making Behavior: A Study From Pakistan. The Business \&Management Review, 4 (3), 81-93.

Robson, C. (2002). Real World Research, Blackwell Publishers, Oxford. 
Rooij, M.V., Lusardi, A. ve Alessie, R. (2011). Financial literacy And Stock Market Participation. Journal of Financial Economics, 101. 449-472.

Sancak, E, Demirci, N. (2012). Ulusal Tasarruflar ve Türkiye'de Sürdürülebilir Büyüme İçin Tasarrufların Önemi, Ekonomik ve Sosyal Araştırmalar Dergisi, Güz 2012, Cilt:8, Yıl:8, Sayı:2, 8:159-198.

Sancak, E. (2016). Bireysel Finans, Scala Yayıncılık, İstanbul.

Sarıgül, H. (2015). Finansal Okuryazarlık Tutum ve Davranış Ölçeği Geliştirme, Geçerlilik ve Güvenilirlik, Yönetim ve Ekonomi Araştırmaları Dergisi, Cilt: 13, Sayı: 1, 200-2018.

Sevim, U., Temizel, F., Bayramoğlu, F., Balı, S., ve Kostakoğlu, F. S. 2018), Girişim Finansmanı, Anadolu Üniversitesi, Yayını No: 3227, Eskişehir.

TDK (2014). http://www.tdk.gov.tr/ (Erişim Tarihi: 30.10.2018).

Temizel, F., Sarıkaya, M. ve Bayram, F. (2010); "Yatırımcı İlişkileri Yönetiminde İletişim Ve Bilgi Teknolojilerinin Rolü: İMKB 50 Endeksi Uygulaması", Atatürk Üniversitesi Íktisadi ve İdari Bilimler Dergisi, Cilt 24, Sayı 2, s. 1-20.

Timur, E. (2018). Finansal Okuryazarlık Düzeyinin Belirlenmesi, Mersin Üniversitesi İktisadi ve İdari Bilimler Fakültesi (İIBF)'nde Bir Araştırma, Sobider, Sosyal Bilimler Dergisi, Yıl: 5, Sayı: 19, Ocak, 528-540.

Türkiye Cumhuriyet Merkez Bankası, (2011). Dünyada ve Türkiye'de Finansal Hizmetlere Erişim ve Finansal Eğitim.

Türkiye Cumhuriyet Merkez Bankası, 2015. Tasarruf-Yatırım Dinamikleri ve Cari İşlemler Dengesi Gelişmeleri, Ankara.

Türkiye Ekonomi Bankası (2015). Finansal Okuryazarlık ve Erişim Endeksi, http://www.teb.com.tr/document/finansalokuryazarlık-ve-erisim-endeksi.pdf 29.10.2018).

Usul, H., Bekçi, İ. ve Eroğlu, A. H. (2002). "Bireysel Yatırımcıların Hisse Senedi Edinimine Etki Eden Sosyo-Ekonomik Etkenler”, Erciyes Üniversitesi İktisadi ve İdari Bilimler Fakültesi Dergisi, Sayı: 19, s. 135-150.

Uygur, E. (2012). Türkiye'de Tasarrufların Seyri ve Etkileyen Bazı Unsurlar, Türkiye Ekonomi Kurumu Tartışma Metni, (108).

Volpe, R. P.; Joseph E. K. ve Chen, H. (2002). A Survey of Investment Literacy Among Online Investors. Financial Counceling and Planning, 13 (1): 1-13.

Wagland, S. (2006). Financial Literacy In The Context of Literacy in General, Fifth Australien Society of Heteredox Economists Conference.

Widdowson, D. and Kim H. (2007). Financial Literacy and Its Role in Promoting a Sound Financial Sistem, Research Bank of New Zealand: Bulletin, 70 (2), 37-47.

Yalçıner, K. ve Aksoy, E. E. (2011). Yatırım Projelerinin Değerlendirilmesi, Detay Yayınaılık, Ankara.

Yazıcıoğlu, Y. ve Erdoğan, S. (2004a). SPSS Uygulamalı Bilimsel Araştırma Yöntemleri. Ankara. Detay Yayıncilı.

Yazıcıoğlu, Y. ve Erdoğan, S. (2004b). Aile Ekonomisi, (Editör: Levent Kılıç), Eskişehir, Eylül. 